Issued by Sandia National Laboratories, operated for the United States Department of Energy by Sandia Corporation.

NOTICE: This report was prepared as an account of work sponsored by an agency of the United States Government. Neither the United States Government, nor any agency thereof, nor any of their employees, nor any of their contractors, subcontractors, or their employees, make any warranty, express or implied, or assume any legal liability or responsibility for the accuracy, completeness, or usefulness of any information, apparatus, product, or process disclosed, or represent that its use would not infringe privately owned rights. Reference herein to any specific commercial product, process, or service by trade name, trademark, manufacturer, or otherwise, does not necessarily constitute or imply its endorsement, recommendation, or favoring by the United States Government, any agency thereof, or any of their contractors or subcontractors. The views and opinions expressed herein do not necessarily state or reflect those of the United States Government, any agency thereof, or any of their contractors.

Printed in the United States of America. This report has been reproduced directly from the best available copy.

Available to DOE and DOE contractors from Office of Scientific and Technical Information

P.O. Box 62

Oak Ridge, TN 37831

Prices available from (703) 605-6000

Web site: http://www.ntis.gov/ordering.htm

Available to the public from

National Technical Information Service

U.S. Department of Commerce

5285 Port Royal Rd

Springfield, VA 22161

NTIS price codes

Printed copy: A03

Microfiche copy: A01

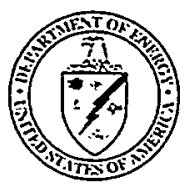




\section{DISCLAIMER}

Portions of this document may be illegible in electronic image products. Images are produced from the best available original document. 
SAND99-2082

Unlimited Release

Printed August 1999

\title{
ELECTROSLAG REMELTING (ESR) SLAGS FOR REMOVAL OF RADIOACTIVE OXIDE CONTAMINANTS FROM STAINLESS STEEL*
}

Annual Report (1998-1999)

\author{
March 30, 1999 \\ Professor Uday B. Pal \\ High Temperature Materials Process Technology Laboratory \\ Department of Manufacturing Engineering \\ Boston University, MA 02215 \\ prepared for: \\ Sandia National Laboratories \\ Liquid Metal Processing Laboratory \\ Albuquerque, NM 87185-1134
}

\begin{abstract}
Decontamination of radioactive contaminated stainless steel using the ESR process is investigated by conducting thermophysical and thermochemical laboratory studies on the slag. The ESR base slag investigated in this research project is $60 \mathrm{wt} \% \mathrm{CaF}_{2}-20 \mathrm{wt} \% \mathrm{CaO}-20 \mathrm{wt} \% \mathrm{Al}_{2} \mathrm{O}_{3}$. In this report, we present the data obtained to date on relevant slag properties, capacity to incorporate the radioactive contaminant (using $\mathrm{CeO}_{2}$ as surrogate, simulant for $\mathrm{PuO}_{2}$ and $\mathrm{UO}_{2}$ ), slag-metal partition coefficient, volatilization rate and volatile species, viscosity, electrical conductivity and surface tension as a function of temperature. The impact of these properties on the ESR decontamination process is presented.
\end{abstract}

This study was performed under Contract BC-4199 for Sandia National Laboratories, Environmental Management Science Program project. 
Intentionally Left Blank 


\section{Table of Contents}

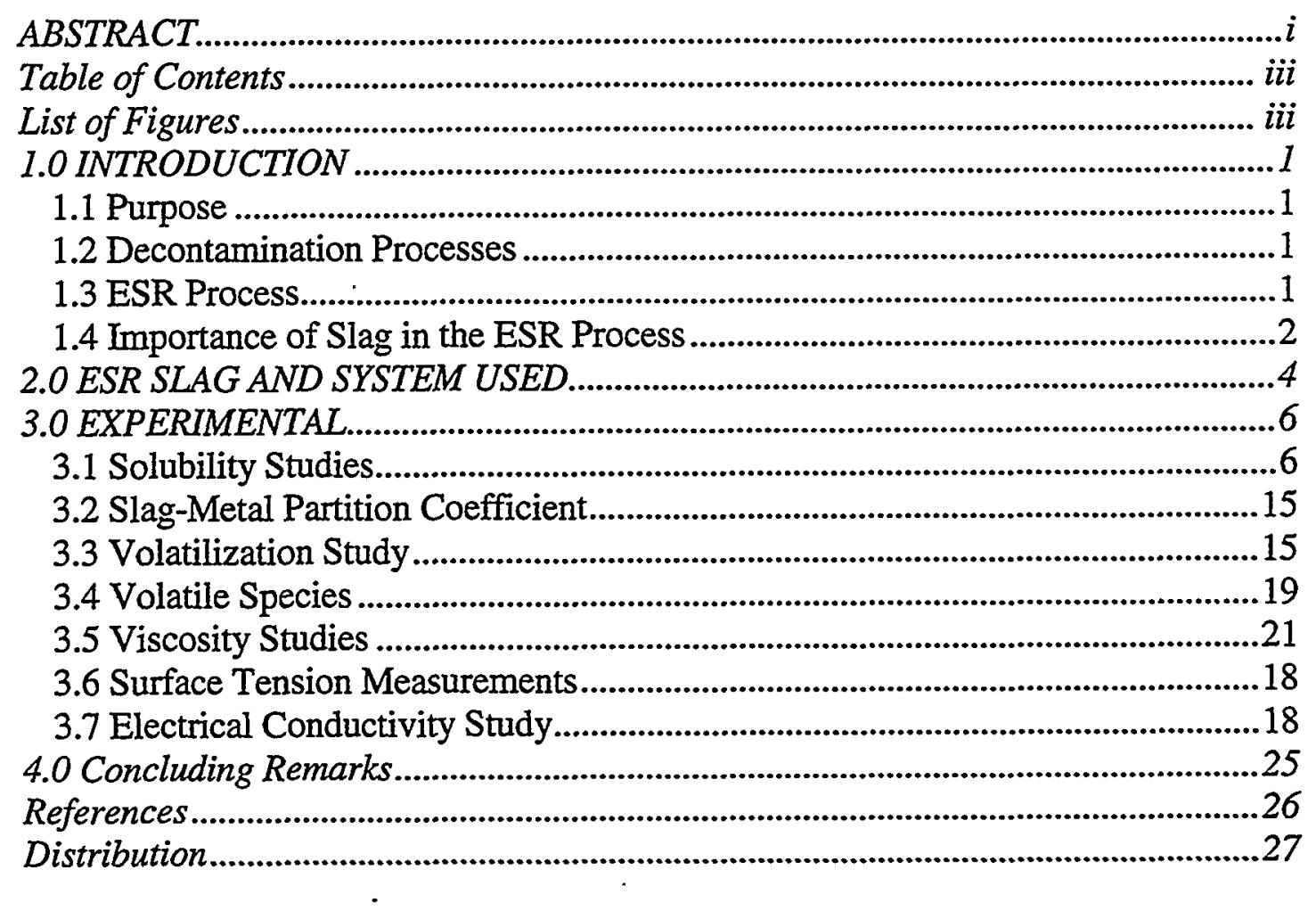

\section{List of Figures}

Figure 1: Schematic of the ESR Furnace 2

Figure 2: Equilibrium Phase Diagram $\quad \cdot \quad \cdot \quad 4$

Figure 3: Experimental Set Up for $\mathrm{CeO}_{2}$ Solubility Study $\quad 7$

Figure 4: BEI of Pure Base Slag 8

Figure 5: $\mathrm{BEI}$ of Base Slag with $0.025 \mathrm{wt} \% \mathrm{CeO}_{2}$

Figure 6: BEI of Base Slag with $0.10 \mathrm{wt} \% \mathrm{CeO}_{2}$

Figure 7: BEI of Base Slag with 0.50wt\% $\mathrm{CeO}_{2}$

Figure 8: $\mathrm{BEI}$ of Base Slag with 1.0wt\% $\mathrm{CeO}_{2}$

Figure 9: BEI of Of Base Slag with 2.5wt\% $\mathrm{CeO}_{2}$

Figure 10: BEI of Base Slag with 4.7wt\% $\mathrm{CeO}_{2}$

Figure 11: $\mathrm{BEI}$ of Base Slag with 8.3wt\% $\mathrm{CeO}_{2}$

Figure 12: $\mathrm{BEI}$ of Base Slag with 13.1wt\% $\mathrm{CeO}_{2}$

Figure 13: $\mathrm{BEI}$ of Base Slag with 23wt\% $\mathrm{CeO}_{2}$

Figure 14: Thermogravimetry Experimental Set Up to Study Volatilization 16

Figure 15: Phase Diagram Of Ce-C-O System 17

Figure 16: Thermogravimetric Experiment with Base Slag 17

Figure 17: Thermogravimetric Experiment of Base Slag with 100ppm CeO $\mathrm{p}_{2} \quad 17$

Figure 18: Comparison of Result of Volatilization Experiments 18

Figure 19: Experimental Setup for Identification of Volatile Species 19 
Figure 20: X-Ray Diffraction Result 19

Figure 21: Experimental Setup for Identification of Volatile Species 20

Figure 22: Mass Spectroscopy Analysis of the Volatile Species 20

Figure 23: Set Up for Viscosity Measurement 21

Figure 24: Arrhenius Plot of Base Slag Viscosity $\quad 21$

Figure 25: Set Up for Surface Tension $\quad 18$

Figure 26: Arrhenius Plot of Base Slag Surface Tension $\quad 18$

Figure 27: Set Up of Electrical Conductivity 23

Figure 28: Arrhenius Plot of Conductivity 23

Figure 29: Calibration Free Conductivity Cell 24

\section{List of Tables}

Table I: Radioactive and Surrogate Compound Properties 5

Table II: Details of the Solubility Experiments 6

Table III: Standards Used in EMP Analysis $\quad 7$

Table IV: EMP Analysis of Base Slag $\quad 8$

Table V: EMP Analysis of Base Slag with $0.025 \mathrm{wt} \% \mathrm{CeO}_{2}$

Table VI: EMP Analysis of Base Slag with $0.10 \mathrm{wt} \% \mathrm{CeO}_{2} \quad 10$

Table VII: EMP Analysis of Base Slag with $0.50 \mathrm{wt} \% \mathrm{CeO}_{2} \quad 10$

Table VIII: EMP Analysis of Base Slag with $1.0 \mathrm{wt} \% \mathrm{CeO}_{2}$

Table IX: EMP Analysis of Base Slag with $2.5 \mathrm{wt} \% \mathrm{CeO}_{2} \quad 12$

Table X: EMP Analysis of Base Slag with 4.7wt\% $\mathrm{CeO}_{2}$

Table XI: EMP Analysis of Base Slag with $8.3 \mathrm{wt} \% \mathrm{CeO}_{2} \quad 13$

Table XI: EMP Analysis of Base Slag with $13.1 \mathrm{wt} \% \mathrm{CeO}_{2}$

Table XIII: EMP Analysis of Base Slag with 23wt\% $\mathrm{CeO}_{2}$ 
Intentionally Left Blank 


\section{Electroslag Remelting (ESR) Slags for Removal of Radioactive Oxide Contaminants from Stainless Steel \\ Annual Report (1998-1999)}

March 30, 1999

\subsection{INTRODUCTION}

\subsection{Purpose}

Downsizing and decommissioning of nuclear facility operations is increasing the stockpile of Radioactive Scrap Metal (RSM). The annual generation of RSM for the entire DOE complex is estimated to be approximately 120,000 metric tons, of which contaminated stainless steel with high chromium and nickel contents constitutes 25-30\% by weight [1]. Disposal of this material not only represents significant resources and value lost, but also necessitates long term monitoring for environmental compliance. The latter results in additional recurring expense. It is desirable to be able to decontaminate the radioactive stainless steel to a very low level that can be recycled or at least used for fabrication of containers for RSM disposal instead of using virgin stainless steel.

\subsection{Decontamination Processes}

The goal of the RSM decontamination process is to reduce the radioactive contaminant to a sufficiently low level so that the metal can be handled safely or reused. Melt decontamination provides an effective means for both consolidation and removing the contaminants from the bulk in a kinetically favorable manner. Various methods of meit decontamination evaluated are Electric Arc Melting, Air and Vacuum Induction Melting, Plasma Melting and Electroslag Remelting (ESR). In this research program, the ESR process with some of its inherent advantages is the subject of the investigation.

\subsection{ESR Process}

In the ESR process (see Figure 1), the RSM forms one of the two electrodes. Joule heating through a molten slag layer maintains the slag temperature between $1700-2000^{\circ} \mathrm{C}$ and melts one end of that consumable electrode. The molten metal droplets from the consumable (RSM) electrode fall through the slag layer. While the metal is in contact 
with the slag, most of the radioactive contaminants from the metal are preferentially incorporated into the slag. The metal droplets are solidified in a water-cooled copper mold and form part of the consolidated and decontaminated ingot underneath the slag layer. This can be easily formed into a useful product by mechanical processes such as rolling, forging etc. The ingot also serves as the other electrode in the process. The slag containing the contaminants is removed as a solid and can be reused or appropriately disposed.

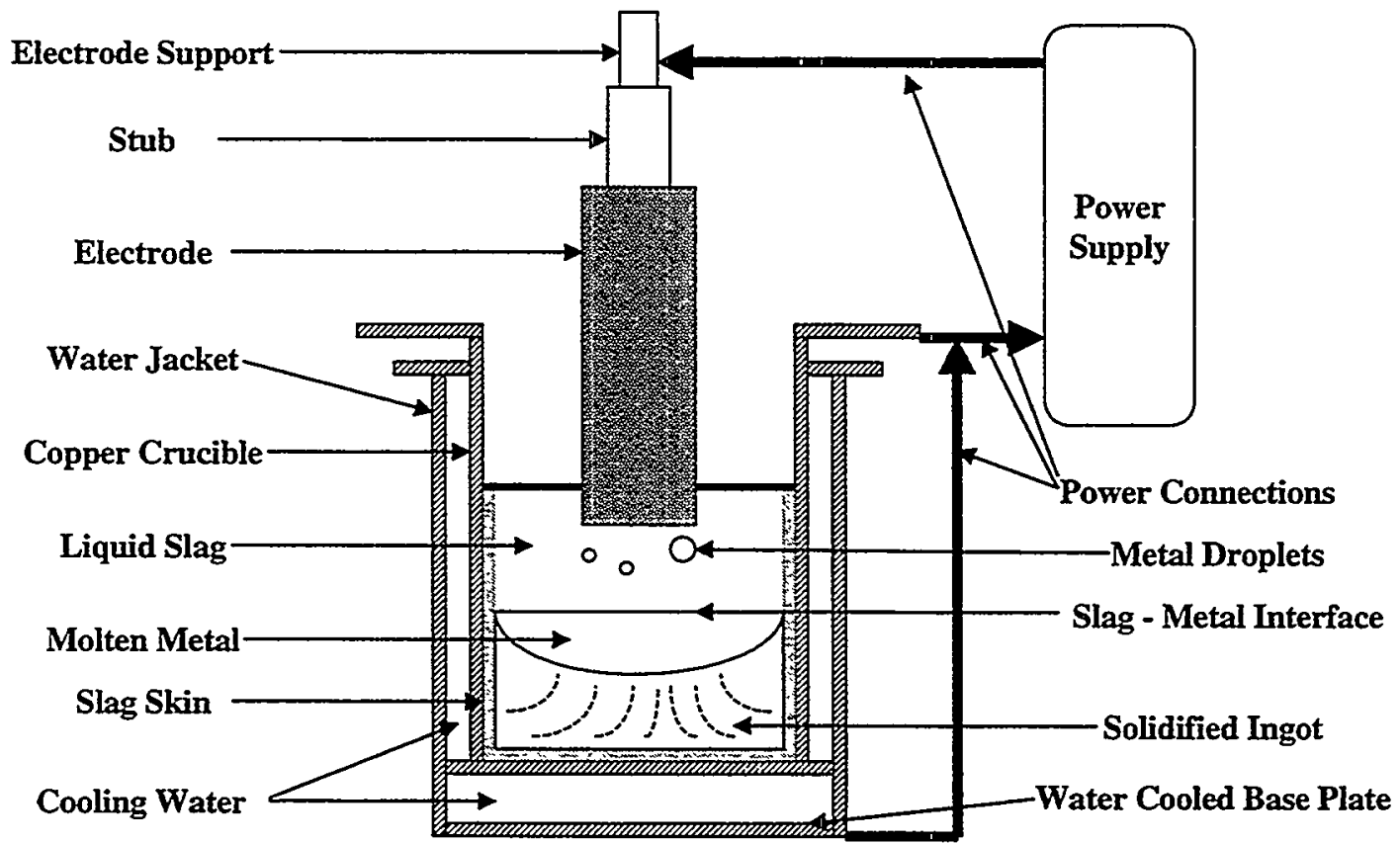

FIGURE 1: SCHEMATIC OF THE ESR FURNACE

\subsection{Importance of Slag in the ESR Process}

The slag in the ESR process is crucial for its success [2]. For instance, it must have a high capacity for incorporating the contaminants with a high partition coefficient between the slag and the metal. Its interfacial properties must be such that it wets the metal for effective removal of the contaminants, but it must not facilitate formation of slag skin over the ingot. Along with surface tension its density and viscosity must be such that it provides sufficient residence time for the metal droplets without adversely affecting slag fluidity and mass transfer properties. The electrical conductivity must be such that it 
provides efficient joule heating while still permitting a reasonable melt rate. The volatilization rate and the volatile species must be known for determining effective means of capture. The solid-state slag structure must be such that the phases formed are stable and non leachable for ease of handling and disposal. It is also desirable to minimize the slag skin around the ingot and concentrate the radioactive contaminants in the slag cap over the ingot. 


\subsection{ESR SLAG AND SYSTEM USED}

The ESR base slag investigated in this research is $60 \mathrm{wt} \% \mathrm{CaF}_{2}-20 \mathrm{wt} \% \mathrm{CaO}-20 \mathrm{wt} \% \mathrm{Al}_{2} \mathrm{O}_{3}$. The ternary plot of the system is shown in Figure 2 [3]. Preliminary ESR trials have shown that this slag can be used to decontaminate radionuclides and chemical surrogates from contaminated stainless steel $[2,4]$. In this program, the potential radioactive contaminants of interest to be removed from the stainless steel are uranium (U), plutonium (Pu), cesium (Cs), strontium (Sr) and technetium (Tc). Due to high oxygen affinity of $\mathrm{U}, \mathrm{Pu}, \mathrm{Cs}, \mathrm{Sr}$ and $\mathrm{Tc}$, these radioactive contaminants are expected to be present as oxides in decommissioned nuclear processing, fabrication or in nuclear reactor facilities either as surface contaminants or lodged in cracks and crevices of piping or other components. The nonradioactive surrogates used to simulate and test these radioactive contaminants are oxides of $\mathrm{Ce}$ and $\mathrm{Hf}$ (for $\mathrm{U}$ and $\mathrm{Pu}$ oxides), $\mathrm{Re}$ (for $\mathrm{Tc}$ oxide) and $\mathrm{Cs}$ and $\mathrm{Sr}$ (for their radioactive counterparts). The properties used for surrogate selection are reported in Table I.

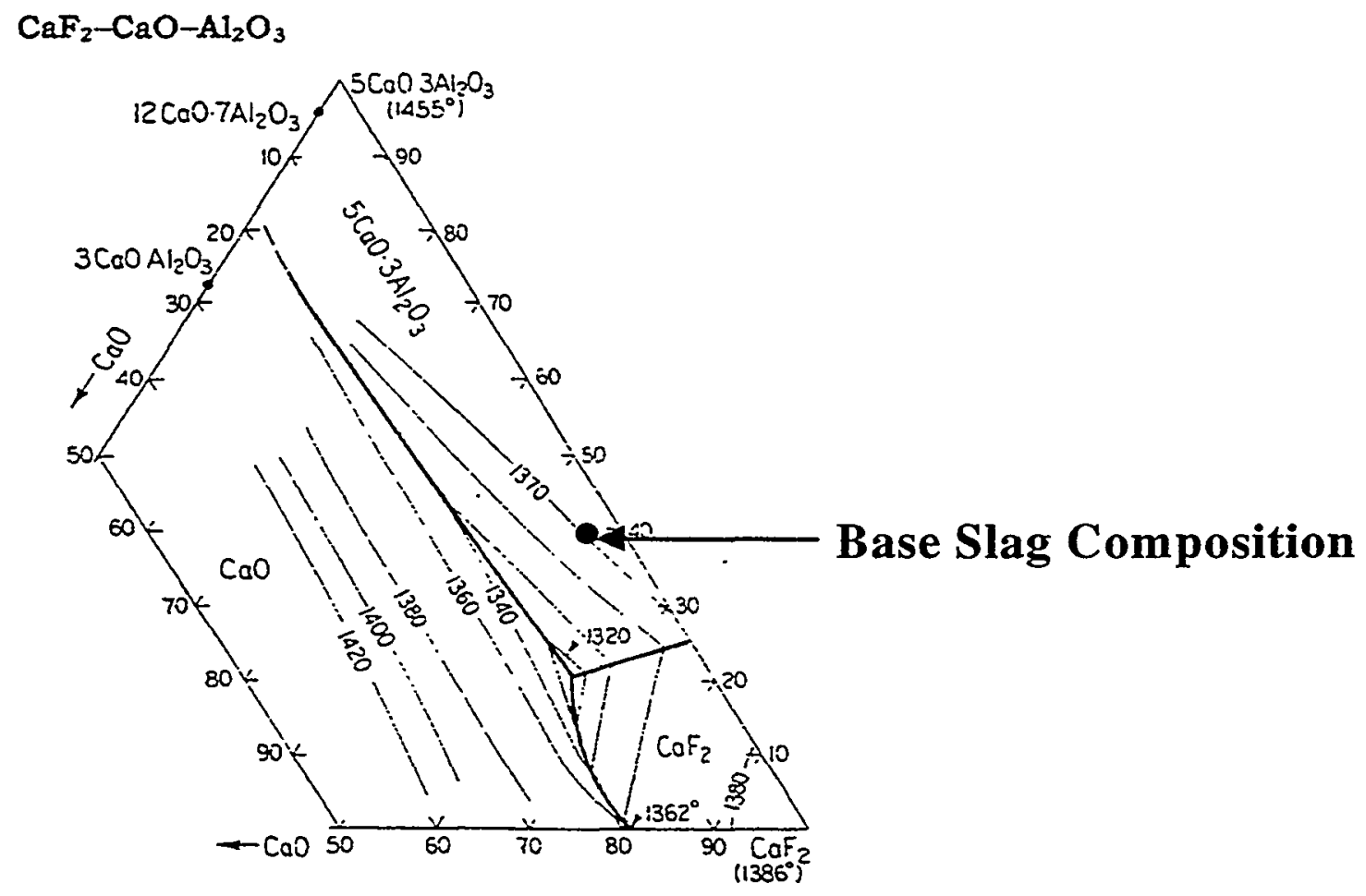

Fig. 1707.-Systern $\mathrm{CaF}_{2}-\mathrm{CaO}-5 \mathrm{CaO} \cdot 3 \mathrm{Al}_{2} \mathrm{O}_{2}$.

W. Eitel, Zement, 27, 30 (1938).

FIGURE 2: EQUILIBRIUM PHASE DIAGRAM 
Table I: Radioactive and Surrogate Compound Properties

\begin{tabular}{|c|c|c|c|c|c|c|c|c|}
\hline $\begin{array}{c}\text { Solid } \\
\text { Compound }\end{array}$ & $\begin{array}{c}\text { Molecular } \\
\text { Weight } \\
\text { (g/mol) }\end{array}$ & $\begin{array}{l}\text { Density } \\
\left(\mathrm{g} / \mathrm{cm}^{3}\right)\end{array}$ & $\begin{array}{c}\text { Melting } \\
\text { Point } \\
\left({ }^{\circ} \mathrm{C}\right) \\
\end{array}$ & $\begin{array}{c}\text { Boiling } \\
\text { Point } \\
\left.{ }^{\circ} \mathrm{C}\right) \\
\end{array}$ & $\begin{array}{l}\text { Oxidatio } \\
\text { n States }\end{array}$ & $\begin{array}{l}\text { Electron } \\
\text { Affinity }\end{array}$ & $\begin{array}{c}\Delta \mathbf{G}^{0}= \\
\Delta \mathrm{H}^{0}-\mathrm{T} \Delta \mathrm{S}^{\circ} \\
(\mathrm{kJJ} / \mathrm{mol})\end{array}$ & $\begin{array}{c}\Delta \mathbf{G}^{0} \\
\text { Temperature } \\
\text { Range }\left({ }^{\circ} \mathrm{C}\right)\end{array}$ \\
\hline $\mathrm{U}$ & 238 & 198.05 & 1132 & 3818 & $3^{+}, 4^{+}, 5^{+}, 6^{+}$ & 1.38 & - & - \\
\hline $\mathrm{UO}_{2}$ & 270 & 10.96 & 2878 & NA & & & $-1084.91-.077822 \mathrm{~T}$ & $25-1227$ \\
\hline $\mathrm{U}_{3} \mathrm{O}_{8}$ & 842 & 8.3 & d. 1300 & $\mathrm{NA}$ & & & NA & NA \\
\hline $\mathrm{Pu}$ & 239.1 & $16.5-17.7$ & $122-639$ & $\mathrm{NA}$ & $3^{+}, 4^{+}, 5^{+}, 6^{+}$ & 1.28 & - & - \\
\hline $\mathrm{PuO}_{2}$ & 271.1 & 11.46 & 2400 & $\mathrm{NA}$ & & & $-1055.83-.066128 \mathrm{~T}$ & $25-2442$ \\
\hline Ce & 140.1 & 6.66 & 799 & 3426 & $3^{+}, 4^{+}$ & 1.12 & - & - \\
\hline $\mathrm{CeO}_{2}$ & 172.1 & 7.13 & 2600 & $\mathrm{NA}$ & & & $-1088.68-.0623 \mathrm{~T}$ & $25-1727$ \\
\hline $\mathrm{Ce}_{2} \mathrm{O}_{3}$ & 328.4 & 6.86 & 1692 & $\overline{N A}$ & & & $-1796.19-.150582 \mathrm{~T}$ & $25-927$ \\
\hline $\mathrm{Hf}$ & 178.5 & 13.31 & 2227 & 4602 & $4^{+}$ & 1.3 & - & - \\
\hline $\mathrm{HfO}_{2}$ & 210.5 & 9.68 & 2812 & $\mathrm{NA}$ & & & $10.46-.005301 \mathrm{~T}$ & $1700-2900$ \\
\hline Tc & 98 & 11.5 & 2200 & 5027 & $4^{+}, 6^{+}, 7^{+}$ & NA & - & - \\
\hline $\mathrm{TcO}_{2}$ & 130 & $\mathrm{NA}$ & 2127 & $\mathrm{NA}$ & & & $-433.044-.054392 \mathrm{~T}$ & $25-927$ \\
\hline $\mathrm{TcO}_{3}$ & 146 & $\mathrm{NA}$ & 927 & NA & & & $-539.736-.077404 \mathrm{~T}$ & $25-127$ \\
\hline Sr & 87.6 & 2.6 & 769 & 1384 & $2^{+}$ & 0.95 & - & - \\
\hline SrO & 103.6 & 4.7 & 2430 & $\mathrm{NA}$ & & & $-592.036-.055522 \mathrm{~T}$ & $25-727$ \\
\hline $\mathrm{Cs}$ & 132.9 & 1.88 & 28.4 & 669 & $1^{+}$ & 0.79 & - & - \\
\hline $\mathrm{Cs}_{2} \mathrm{O}$ & 281.8 & 4.25 & $\mathrm{NA}$ & $\mathrm{NA}$ & & & $-345.975-.146858 \mathrm{~T}$ & $25-490$ \\
\hline $\operatorname{Re}$ & 186.2 & 20.53 & 3180 & 5627 & $4^{+}, 6^{+}, 7^{+}$ & 1.9 & - & - \\
\hline $\mathrm{ReO}_{2}$ & 218.2 & 11.4 & $\mathrm{NA}$ & NA & & & $-448.943-.04782 T \mathrm{~T}$ & $25-1127$ \\
\hline $\mathrm{Re}_{2} \mathrm{O}_{7}$ & 484.4 & 6.1 & 297 & Subl. 250 & & & $0.084-.000205 \mathrm{~T}$ & $140-327$ \\
\hline
\end{tabular}

This paper reports the results of an ongoing research effort. The ESR slag that is investigated here is $60 \mathrm{wt} \% \mathrm{CaF}_{2}-20 \mathrm{wt} \% \mathrm{CaO}-20 \mathrm{wt} \% \mathrm{Al}_{2} \mathrm{O}_{3}$ with and without $\mathrm{xCeO}_{2}\left(\mathrm{CeO}_{2}\right.$ is the nonradioactive surrogate for $U$ and $P u$ oxides); ' $x$ ' varying from $250 \mathrm{ppm}$ to $25 \mathrm{wt} \%$. The investigation conducted included measurements of $\mathrm{CeO}_{2}$ solubility in the slag, slagmetal partition coefficient for $\mathrm{Ce}$, slag volatilization, viscosity, electrical conductivity and surface tension. The measurements were made primarily between $1400-1650^{\circ} \mathrm{C}$ and were extrapolated to higher temperatures by utilizing the Arrhenius relationship. 


\subsection{EXPERIMENTAL}

\subsection{Solubility Studies}

Experiments were conducted in an open-air induction furnace by melting and equilibrating $10 \mathrm{~g}$ of either base slag $\left(60 \mathrm{wt} \% \mathrm{CaF}_{2}-20 \mathrm{wt} \% \mathrm{CaO}-20 \mathrm{wt}_{2} \mathrm{Al}_{2} \mathrm{O}_{3}\right)$ or $10 \mathrm{~g}$ of base slag mixed with different amounts of ceria (Table $\mathrm{I}$ ). The experimental setup is schematically shown in Figure 3. The base slag was prepared by self-milling the constituent powders. The ceria (produced by sol-gel) was sintered in air at $1695^{\circ} \mathrm{C}$ to a theoretical density of over $90 \%$ as a $3 / 4$ " closed-porosity pellet. Portions of the ceria pellet were broken and added to the slag as needed. The slag samples were all isothermally held at $1500^{\circ} \mathrm{C}$ for 15 minutes and air quenched. This process was determined to be adequate for equilibrating the molten slag.

The quenched graphite crucible was sectioned along the central axis with a low speed diamond saw using an oil lubricant. The sample was cleaned with methanol and mounted either in an acrylic or epoxy medium. The sample was polished with diamond paste and cleaned during the process with methanol.

Table II: Details of the Solubility Experiments

\begin{tabular}{|c|c|c|c|}
\hline $\begin{array}{c}\text { Mass of } \\
\text { Base Slag } \\
(\mathbf{g})\end{array}$ & $\begin{array}{c}\text { Mass of } \\
\mathbf{C e O}_{2} \\
(\mathbf{g})\end{array}$ & $\begin{array}{c}\text { Weight } \\
\text { Percent of } \\
\mathbf{C e O}_{2}\end{array}$ & $\begin{array}{c}\text { Results of } \\
\text { Air Quenched } \\
\left(\text { from } \mathbf{1 5 0 0}^{\circ} \mathbf{C} \text { ) }\right.\end{array}$ \\
\hline 10.000 & 0.000 & 0.00 & 2-phase structure \\
\hline 10.155 & 0.0025 & 0.025 & 2-phase structure \\
\hline 9.973 & 0.010 & 0.10 & 2-phase structure \\
\hline 10.065 & 0.051 & 0.50 & 2-phase structure \\
\hline 10.010 & 0.105 & 1.00 & 2-phase structure \\
\hline 10.000 & 0.254 & 2.50 & 2-phase structure \\
\hline 10.060 & 0.495 & 4.70 & 2-phase structure \\
\hline 10.907 & 0.990 & 8.30 & 3-phase structure \\
\hline 10.028 & 1.510 & 13.10 & 3-phase structure \\
\hline 10.031 & 2.996 & 23.00 & 3-phase structure \\
\hline
\end{tabular}

The polished samples were analyzed with Electron Micro Probe (EMP) JEOL SuperProbe 7300. Wavelength Dispersed Spectroscopy was used for the chemical analysis; the standards used are shown in Table III. A light element detector was used for 
the fluorine and oxygen analysis. Image analysis was used to determine the fraction of each type of phase present. By combining the image analysis with the composition analysis of the phases, a comparison was made between the analyzed and theoretical composition of the slag.

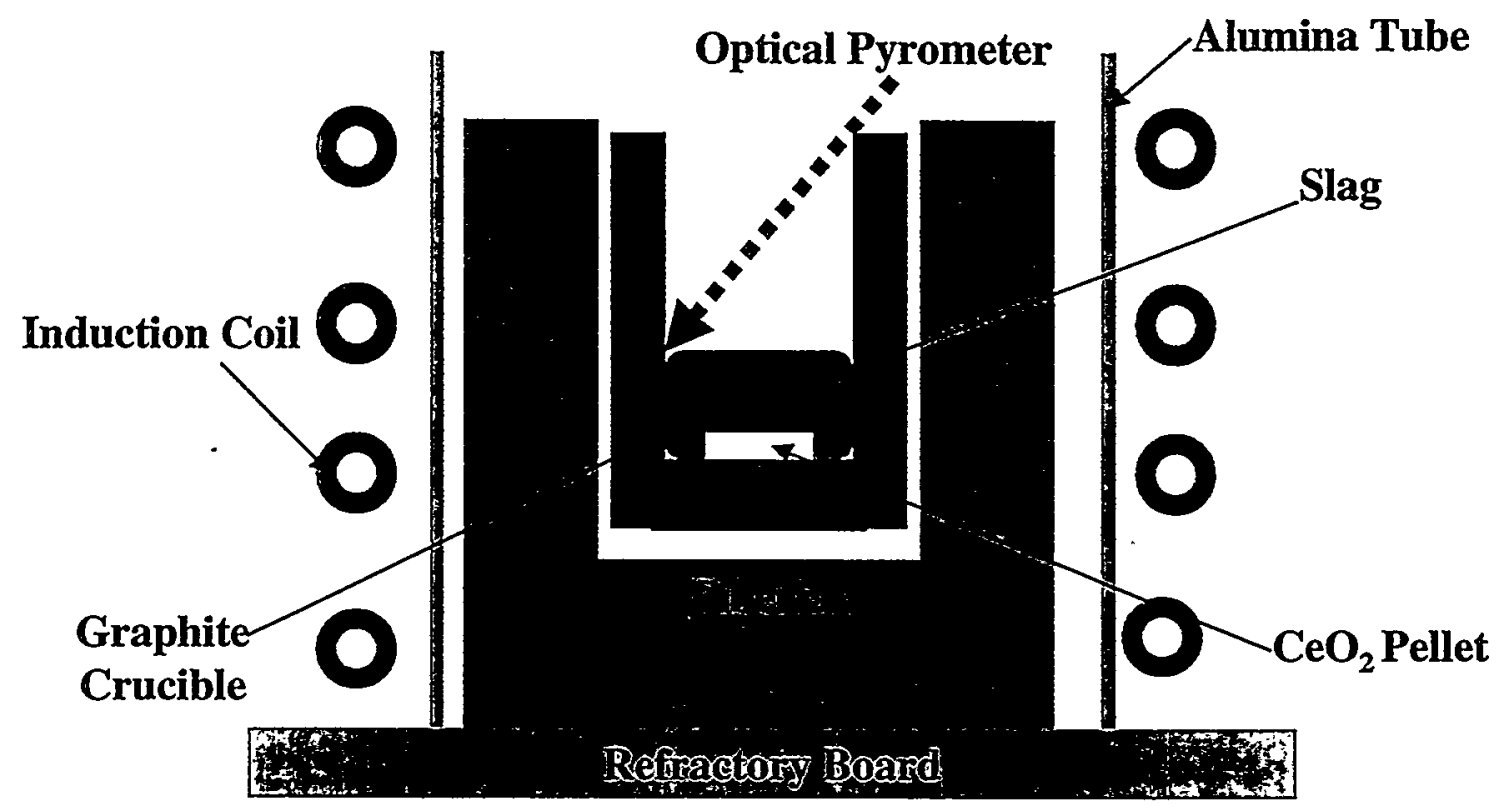

FIGURE 3: EXPERIMENTAL SET UP FOR $\mathrm{CEO}_{2}$ SOLUBILITY STUDY

Table III: Standards Used in EMP Analysis

\begin{tabular}{|c|c|c|c|c|c|}
\hline Element & $\mathrm{F}$ & $\mathrm{Ce}$ & $\mathrm{Al}$ & $\mathrm{Ca}$ & $\mathrm{O}$ \\
\hline Standard & $\mathrm{CaF}_{2}$ & $\mathrm{CePO}_{4}$ & $\mathrm{Al}_{2} \mathrm{O}_{3}$ & $\mathrm{CaAl}_{2} \mathrm{SiO}_{8}$ & $\mathrm{Al}_{2} \mathrm{O}_{3}$ \\
\hline
\end{tabular}

EMP analyses showed that the air-quenched base slag is homogeneous and has a twophase structure, one is darker than the other. The backscattered electron image (BEI) and the composition of the two phases are shown in Figure 4 and Table IV, respectively. The dark phase contained $\mathrm{Al}-\mathrm{Ca}-\mathrm{O}-\mathrm{F}$. If we assume that the fluorine is associated with $\mathrm{Ca}$ as $\mathrm{CaF}_{2}$, then the remaining $\mathrm{Al}-\mathrm{Ca}-\mathrm{O}$ had a composition that closely matched $5 \mathrm{CaO}-3 \mathrm{Al}_{2} \mathrm{O}_{3}$. The lighter phase contained $\mathrm{Ca}-\mathrm{F}$ and its composition matched $\mathrm{CaF}_{2}$. The dark-colored phase (Al-Ca-O-F), solidified first, and the Ca-F phase which is the light colored phase solidified later. These observations agree with the expected crystallization path of the 
slag (Figure 2). When $\mathrm{CeO}_{2}$ was added to the slag up to $4.7 \mathrm{wt} \%$, the air-quenched slag still had the same two-phase structure. The higher melting Al-Ca-O-F phase had a higher concentration of $\mathrm{Ce}$ in solid solution and the $\mathrm{Ca}-\mathrm{F}$ phase had a much lower concentration of Ce. These observations are shown in Figures 5-10 and Tables V-X. It is interesting to note that when the $\mathrm{CeO}_{2}$ content is $2.5 \mathrm{wt} \%$ or more in the base slag, the $\mathrm{BEI}$ of the Al$\mathrm{Ca}-\mathrm{O}-\mathrm{F}$ phase with $\mathrm{Ce}$ in solid solution changes from dark to light. This is due to the variable $\mathrm{Ce}$ content. When the $\mathrm{CeO}_{2}$ content was $8.3 \mathrm{wt} \%$ or more, there appeared a third crystalline Ce-rich phase that grew in size as the $\mathrm{CeO}_{2}$ content increased. This is shown in Figures 11-13 and the composition of the phases are listed in Tables XI-XIII. However, these high $\mathrm{CeO}_{2}$ levels may not be interest to the ESR decontamination process, because the level of $\mathrm{CeO}_{2}$ in the slag phase is not expected to exceed a couple 1000ppm.

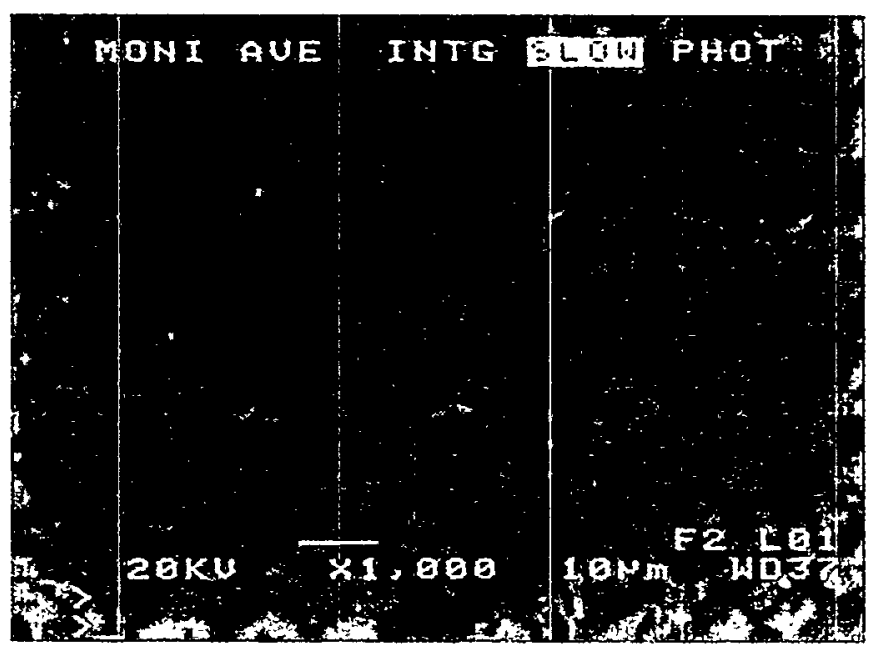

FIGURE 4: BEI OF PURE BASE SLAG

Table IV: EMP Analysis of Base Slag

\begin{tabular}{|l|c|c|c|c|c|c|c|c|c|c|c|c|}
\hline & \multicolumn{9}{|c|}{ Weight\% } & \multicolumn{6}{c|}{ Atomic\% } \\
\hline Phase & Ca & Al & Ce & O & F & Total & Ca & Al & Ce & O & F & Total \\
\hline Dark & 40.2 & 18.76 & 0.048 & 33.09 & 9.47 & 101.56 & 23.514 & 16.298 & 0.008 & 48.49 & 11.69 & 100 \\
\hline Light & 54.9 & 0.409 & 0.063 & 0 & 47.02 & 102.4 & 35.483 & 0.3922 & 0.012 & 0 & 64.11 & 100 \\
\hline
\end{tabular}

\begin{tabular}{|l|c|c|c|c|c|c|}
\hline Composition & 47.77413 & 9.304 & 0.055 & 16.04 & 28.82 & 101.99 \\
\hline Theoretical & 45.1 & 10.6 & 0 & 15.1 & 29.2 & \\
\hline
\end{tabular}




\section{Top}

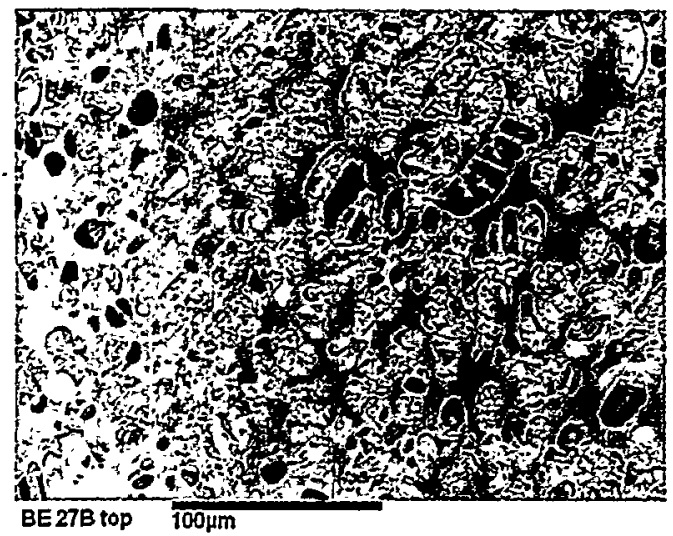

Bottom

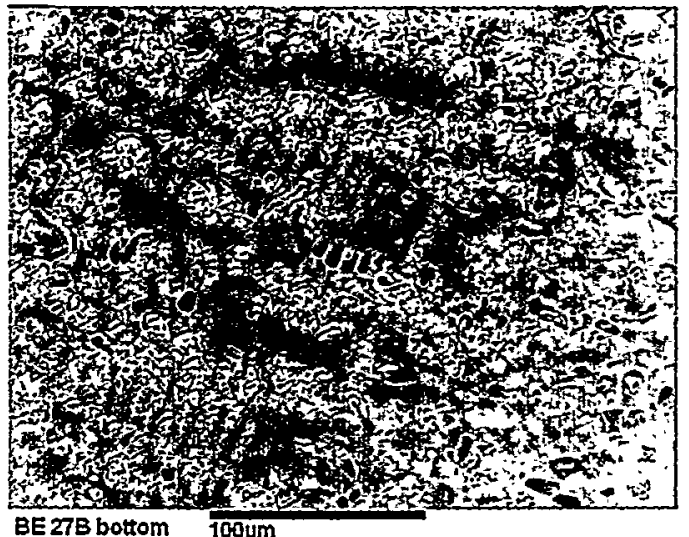

FIGURE 5: BEI OF BASE SLAG WITH 0.025WT\% CEO2

Table V: EMP Analysis of Base Slag with $0.025 w t \% \mathrm{CeO} 2$

\begin{tabular}{|l|c|c|c|c|c|c|c|c|c|c|c|c|}
\hline & \multicolumn{9}{|c|}{ Weight\% } & \multicolumn{6}{c|}{ Atomic\% } \\
\hline Phase & Ca & Al & Ce & O & F & Total & Ca & Al & Ce & O & F & Total \\
\hline Top Light & 57.57 & 0.021 & 0.036 & 0 & 48.08 & 105.7 & 36.1844 & 0.0195 & 0.007 & 0 & 63.79 & 100 \\
\hline Top Dark & 36.89 & 22.55 & 0.063 & 35.2 & 7.51 & 102.22 & 21.1427 & 19.208 & 0.01 & 50.55 & 9.088 & 100 \\
\hline Bottom Light & 57.55 & 0.036 & 0.047 & 0 & 47.96 & 105.59 & 36.2311 & 0.0336 & 0.008 & 0 & 63.73 & 100 \\
\hline Bottom Dark & 36.73 & 22.99 & 0.009 & 35.39 & 6.75 & 101.87 & 21.1306 & 19.648 & 0.001 & 51.02 & 8.2 & 100 \\
\hline
\end{tabular}

\begin{tabular}{|l|c|c|c|c|c|c|}
\hline Composition Top & 45.142 & 13.56 & 0.052 & 21.15 & 23.7 & 103.61 \\
\hline Composition Bottor & 45.3356 & 13.5 & 0.024 & 20.76 & 23.78 & 103.41 \\
\hline Theoretical & 45.1 & 10.58 & 0.02 & 15.12 & 29.2 & \\
\hline
\end{tabular}<smiles>[194In]</smiles>

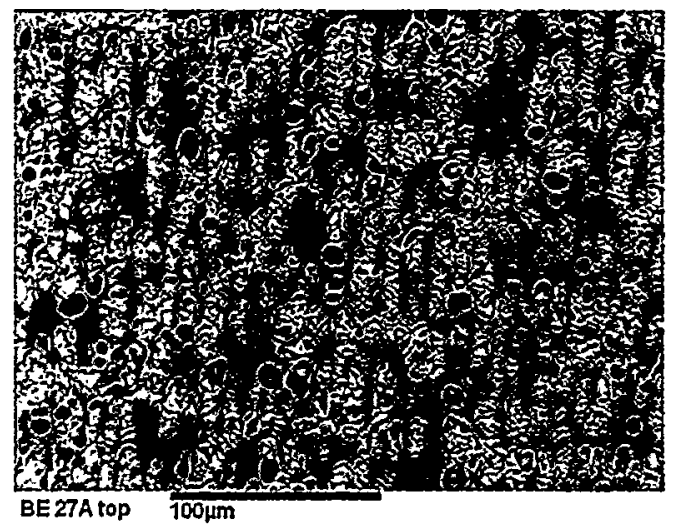

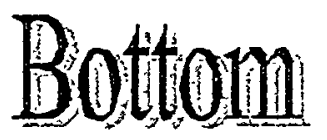

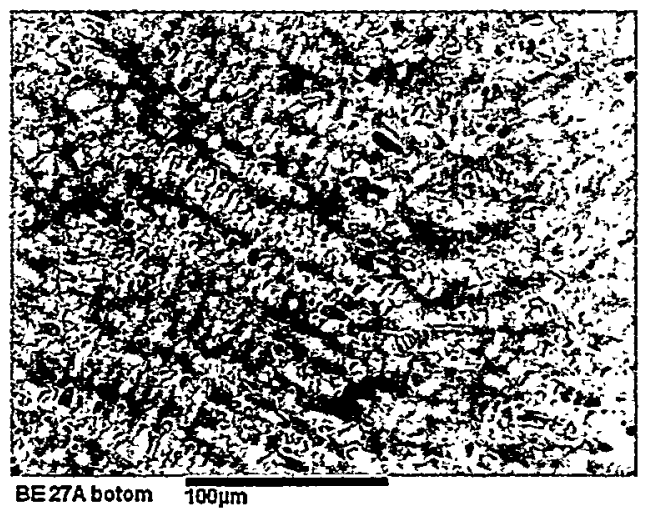

FIGURE 6: BEI OF BASE SLAG WITH 0.10WT\% CEO2 
Table VI: EMP Analysis of Base Slag with 0.10wt $\% \mathrm{CeO}_{2}$

\begin{tabular}{|l|c|c|c|c|c|c|c|c|c|c|c|c|}
\hline & \multicolumn{9}{|c|}{ Weight\% } & \multicolumn{6}{c|}{ Atomic\% } \\
\hline Phase & Ca & Al & Ce & O & F & Total & Ca & Al & Ce & O & F & Total \\
\hline Top Light & 57.7 & 0.025 & 0.037 & 0 & 47.43 & 105.2 & 36.5523 & 0.0235 & 0.007 & 0 & 63.42 & 100 \\
\hline Top Dark & 36.91 & 23 & 0.262 & 35.85 & 6.97 & 103 & 21.0042 & 19.45 & 0.043 & 51.13 & 8.374 & 100 \\
\hline Bottom Light & 56.7 & 0.018 & 0.039 & $\mathbf{0}$ & 47.58 & 104.34 & 36.0783 & 0.0173 & 0.007 & 0 & 63.9 & 100 \\
\hline Bottom Dark & 39.89 & 19.79 & 0.165 & 35.86 & 7.78 & 103.49 & 22.7111 & 16.751 & 0.027 & 51.16 & 9.35 & 100 \\
\hline
\end{tabular}

\begin{tabular}{|l|c|c|c|c|c|c|}
\hline Composition Top & 45.5824 & 13.42 & 0.168 & 20.90 & 23.85 & 103.91 \\
\hline Composition Bottom & 46.84251 & 11.61 & 0.113 & 21.03 & 24.24 & 103.84 \\
\hline Theoretical & 45.1 & 10.58 & 0.081 & 15.12 & 29.2 & \\
\hline
\end{tabular}
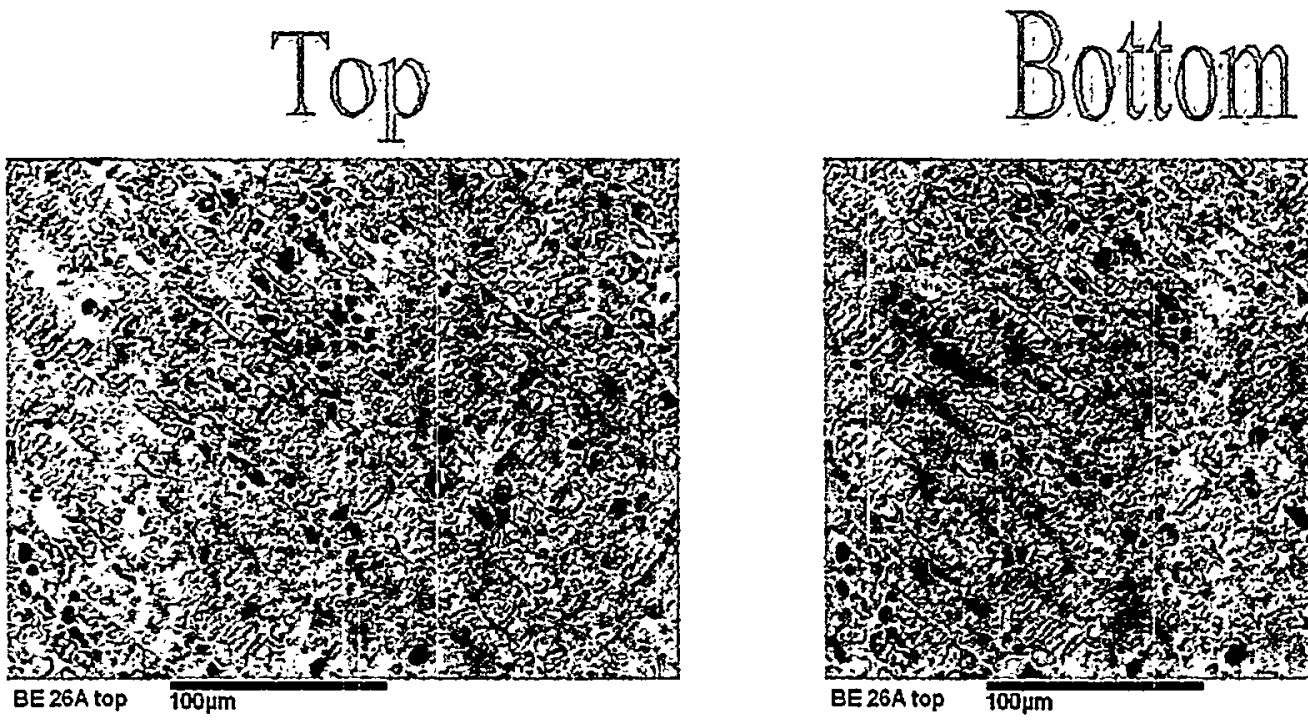

FIGURE 7: BEI OF BASE SLAG WITH 0.50WT\% CEO2

Table VII: EMP Analysis of Base Slag with $0.50 \mathrm{wt} \% \mathrm{CeO}_{2}$

\begin{tabular}{|l|c|c|c|c|c|c|c|c|c|c|c|c|}
\hline & \multicolumn{9}{|c|}{ Weight\% } & \multicolumn{6}{|c|}{ Atomic\% } \\
\hline Phase & Ca & Al & Ce & O & F & Total & Ca & Al & Ce & O & F & Total \\
\hline Top Light & 56.28 & 0.054 & 0.193 & 0 & 48.43 & 140.96 & 35.4797 & 0.0505 & 0.035 & 0 & 64.43 & 100 \\
\hline Top Dark & 36.36 & 22.41 & 0.736 & 36.55 & 6.27 & 102.32 & 20.8087 & 19.063 & 0.12 & 52.43 & 7.577 & 100 \\
\hline Bottom Light & 55 & 0.486 & 0.149 & 0.73 & 47.5 & 103.86 & 34.8506 & 0.4577 & 0.027 & 1.153 & 63.51 & 100 \\
\hline Bottom Dark & 36.12 & 22.85 & 0.779 & 35.3 & 7.11 & 102.17 & 20.787 & 19.546 & 0.128 & 50.9 & 8.635 & 100 \\
\hline
\end{tabular}

\begin{tabular}{|l|c|c|c|c|c|c|}
\hline Composition Top & 44.83883 & 12.89 & 0.505 & 20.99 & 24.22 & 103.45 \\
\hline Composition Bottom & 43.60199 & 13.99 & 0.529 & 21.6 & 23.12 & 102.83 \\
\hline Theoretical & 44.8745 & 10.53 & 0.415 & 15.05 & 29.05 & \\
\hline
\end{tabular}




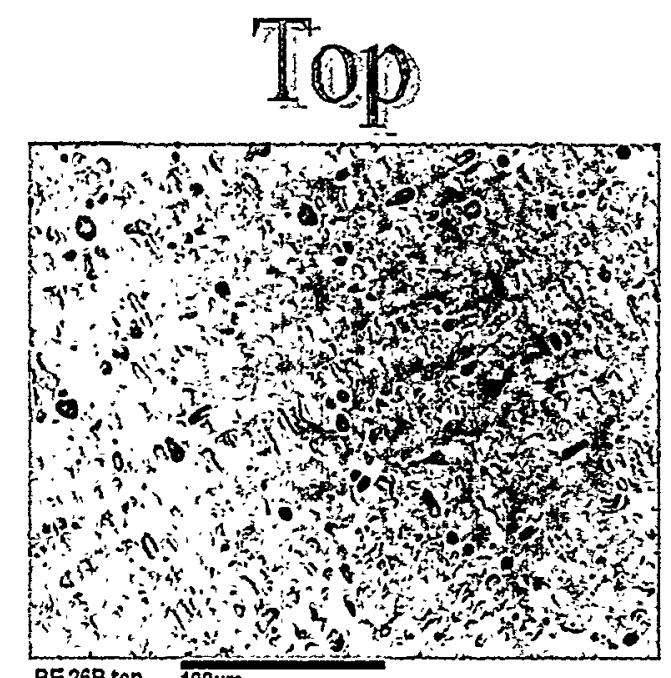

FIGURE 8: BEI OF BASE SLAG WITH 1.0WT\% CEO2

\section{Bottom}

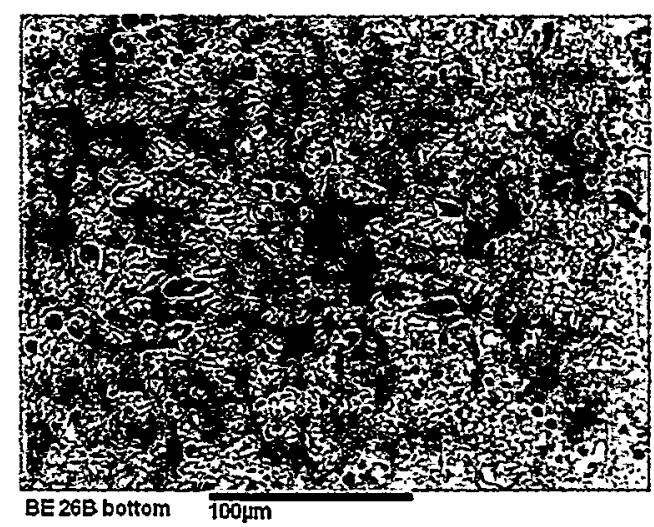

Table VIII: EMP Analysis of Base Slag with $1.0 \mathrm{wt} \% \mathrm{CeO}_{2}$

\begin{tabular}{|c|c|c|c|c|c|c|c|c|c|c|c|c|}
\hline & \multicolumn{6}{|c|}{ Weight\% } & \multicolumn{6}{|c|}{ Atomic\% } \\
\hline Phase & $\mathbf{C a}$ & Al & $\mathrm{Ce}$ & 0 & F & Total & $\mathbf{C a}$ & AI & $\mathrm{Ce}$ & 0 & $\mathbf{F}$ & Total \\
\hline Top Light & 54.54 & 0.054 & 0.281 & 0 & 48.89 & 103.77 & 34.5419 & 0.051 & 0.051 & 0 & 65.36 & 100 \\
\hline Top Dark & 35.29 & 22.8 & 1.518 & 36.01 & 6.56 & 102.17 & 20.3154 & 19.503 & 0.25 & 51.96 & 7.969 & 100 \\
\hline Bottom Light & 55.82 & 0.056 & 0.262 & 0 & 46.97 & 103.11 & 35.9907 & 0.0535 & 0.048 & 0 & 63.91 & 100 \\
\hline Bottom Dark & 35.32 & 22.84 & 1.545 & 35.4 & 6.48 & 101.59 & 20.5254 & 19.724 & 0.257 & 51.55 & 7.949 & 100 \\
\hline
\end{tabular}

\begin{tabular}{|l|c|c|c|c|c|c|}
\hline Composition Top & 41.95525 & 14.92 & 1.09 & 23.54 & 21.22 & 102.73 \\
\hline Composition Bottom & 42.81487 & 14.51 & 1.076 & 22.46 & 21.28 & 102.14 \\
\hline Theoretical & 44.63096 & 10.47 & 0.855 & 14.98 & 28.9 & \\
\hline
\end{tabular}
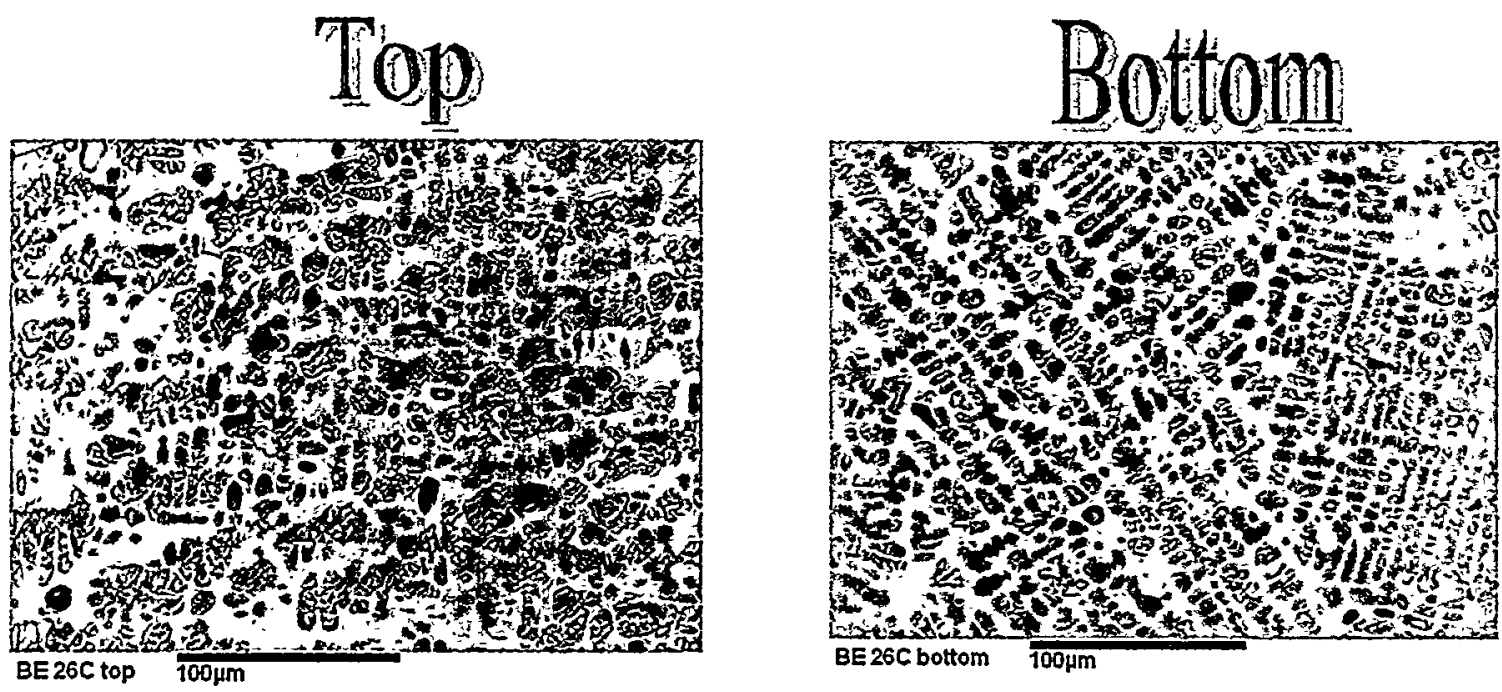

FIGURE 9: BEI OF BASE SLAG WITH 2.5WT\% CEO2 
Table IX: EMP Analysis of Base Slag with $2.5 \mathrm{wt} \% \mathrm{CeO}_{2}$

\begin{tabular}{|l|c|c|c|c|c|c|c|c|c|c|c|c|}
\hline & \multicolumn{9}{|c|}{ Weight\% } & \multicolumn{4}{c|}{ Atomic\% } \\
\hline Phase & Ca & Al & Ce & O & F & Total & Ca & Al & Ce & O & F & Total \\
\hline Top Light & 34.8 & 22.06 & 3.63 & 35.54 & 6.51 & 102.54 & 20.2983 & 19.129 & 0.606 & 51.95 & 8.015 & 100 \\
\hline Top Dark & 52.52 & 0.023 & 0.574 & 0 & 51.5 & 104.63 & 32.5361 & 0.0207 & 0.102 & 0 & 67.34 & 100 \\
\hline Bottom Light & 52.07 & 0.035 & 0.565 & 0 & 51.7 & 104.38 & 32.2599 & 0.0322 & 0.1 & 0 & 67.61 & 100 \\
\hline Bottom Dark & 34.46 & 22.26 & 3.55 & 35.47 & 6.98 & 102.73 & 20.0156 & 19.215 & 0.591 & 51.63 & 8.549 & 100 \\
\hline
\end{tabular}

\begin{tabular}{|l|c|c|c|c|c|c|}
\hline Composition Top & 43.81416 & 10.85 & 2.076 & 17.46 & 29.4 & 103.6 \\
\hline Composition Botton & 43.03607 & 11.44 & 2.096 & 18.2 & 28.76 & 103.52 \\
\hline Theoretical & 43.98152 & 10.29 & 2.01 & 14.79 & 28.4 & \\
\hline
\end{tabular}
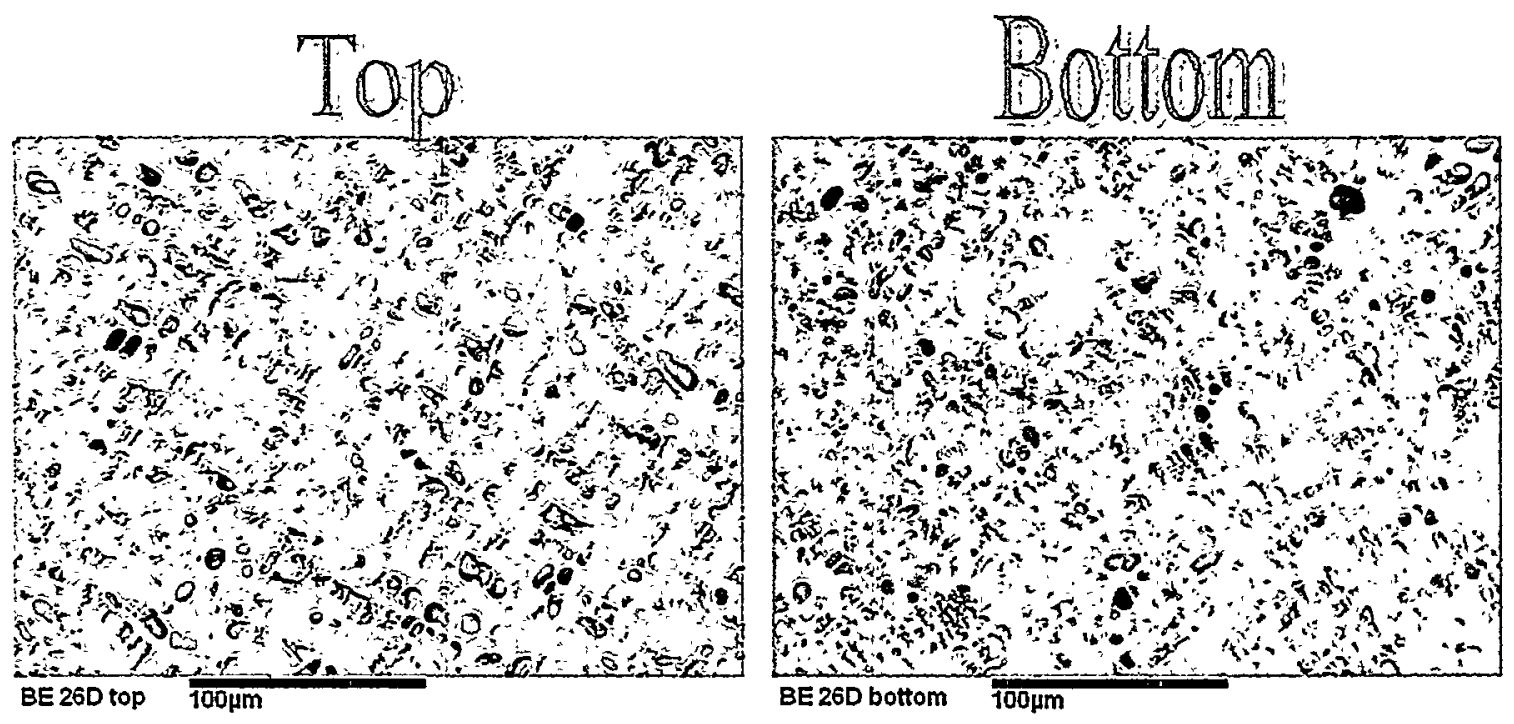

FIGURE 10: BEI OF BASE SLAG WITH 4.7WT\% CEO2

Table X: EMP Analysis of Base Slag with $4.7 \mathrm{wt} \% \mathrm{CeO}_{2}$

\begin{tabular}{|l|c|c|c|c|c|c|c|c|c|c|c|c|}
\hline & \multicolumn{9}{|c|}{ Weight\% } & \multicolumn{4}{c|}{ Atomic\% } \\
\hline Phase & Ca & Al & Ce & O & F & Total & Ca & Al & Ce & O & F & Total \\
\hline Top Light & 32.75 & 21.24 & 6.84 & 34.70 & 5.40 & 100.93 & 19.8921 & 19.179 & 1.188 & 52.82 & 6.922 & 100 \\
\hline Top Dark & 48.43 & 0.044 & 1.065 & 0.00 & 52.88 & 102.42 & 30.1946 & 0.0404 & 0.19 & 0 & 69.58 & 100 \\
\hline Bottom Light & 32.82 & 21.25 & 6.79 & 34.61 & 6.90 & 102.37 & 19.5788 & 18.843 & 1.159 & 51.73 & 8.687 & 100 \\
\hline Bottom Dark & 48.85 & 0.028 & 1.067 & 0.00 & 53.06 & 103 & 30.306 & 0.0262 & 0.189 & 0 & 69.48 & 100 \\
\hline
\end{tabular}

\begin{tabular}{|l|c|c|c|c|c|c|}
\hline Composition Top & 40.4332 & 10.85 & 4.01 & 17.7 & 28.67 & 101.66 \\
\hline Composition Botton & 41.35002 & 9.957 & 3.745 & 16.19 & 31.46 & 102.71 \\
\hline Theoretical & 42.9803 & 10.08 & 4.032 & 14.5 & 27.83 & \\
\hline
\end{tabular}



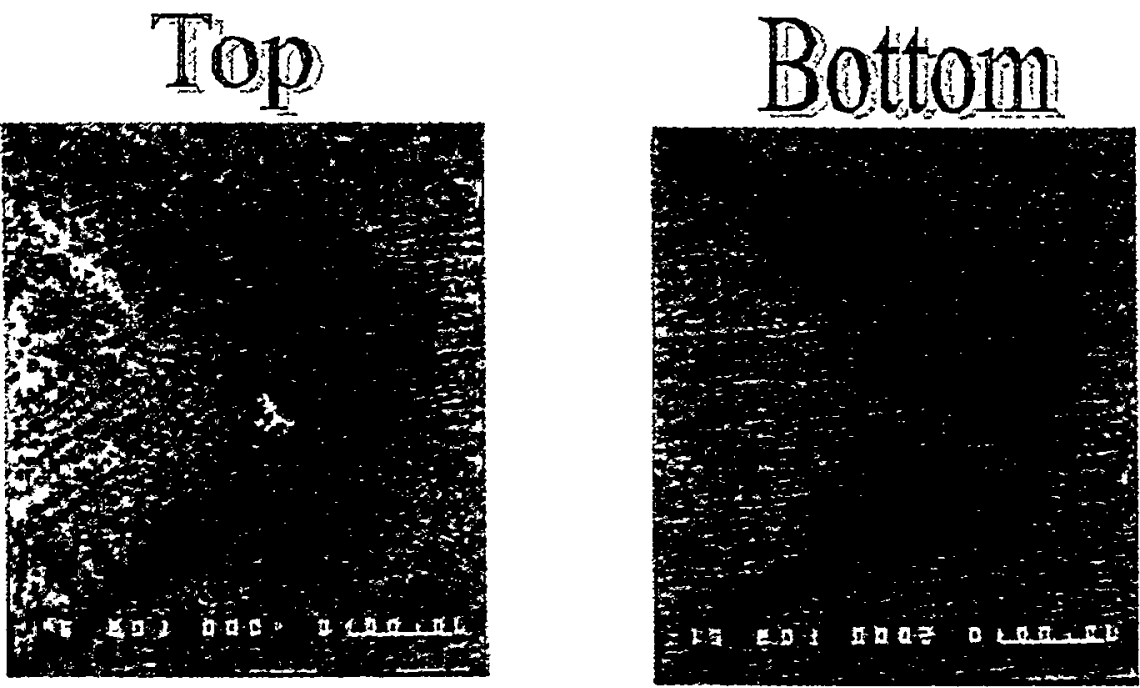

FIGURE 11: BEI OF BASE SLAG WITH 8.3WT\% CEO2

Table XI: EMP Analysis of Base Slag with 8.3wt\% $\mathrm{CeO}_{2}$

\begin{tabular}{|l|c|c|c|c|c|c|c|c|c|c|c|c|}
\hline & \multicolumn{9}{|c|}{ Weight\% } & \multicolumn{4}{c|}{ Atomic\% } \\
\hline Phase & Ca & Al & Ce & O & F & Total & Ca & Al & Ce & O & F & Total \\
\hline Top Light & 30.36 & 21.25 & 12.45 & 35.54 & 7.84 & 107.44 & 17.749 & 18.451 & 2.082 & 52.04 & 9.674 & 100 \\
\hline Top Dark & 46.46 & 1.223 & 2.663 & 3.18 & 39.79 & 93.32 & 32.964 & 1.289 & 0.54 & 5.644 & 59.56 & 100 \\
\hline Top Very Light & 8.09 & 16.12 & 52.2 & 23.91 & 2.287 & 102.6 & 7.242 & 21.441 & 13.37 & 53.63 & 4.32 & 100 \\
\hline Bottom Light & 30.94 & 20.01 & 12.42 & 30.57 & 6.09 & 100.02 & 20.136 & 19.343 & 2.313 & 49.85 & 8.356 & 100 \\
\hline Bottom Dark & 46.11 & 3.06 & 3.65 & 11.08 & 39.85 & 103.75 & 28.198 & 2.7797 & 0.638 & 16.97 & 51.41 & 100 \\
\hline
\end{tabular}

\begin{tabular}{|l|c|c|c|c|c|c|}
\hline Overall Composition & 39.11035 & 10.37 & 7.131 & 17.95 & 25.2 & 99.763 \\
\hline Theoretical & 41.07 & 9.63 & 8.94 & 13.77 & 26.59 & \\
\hline
\end{tabular}
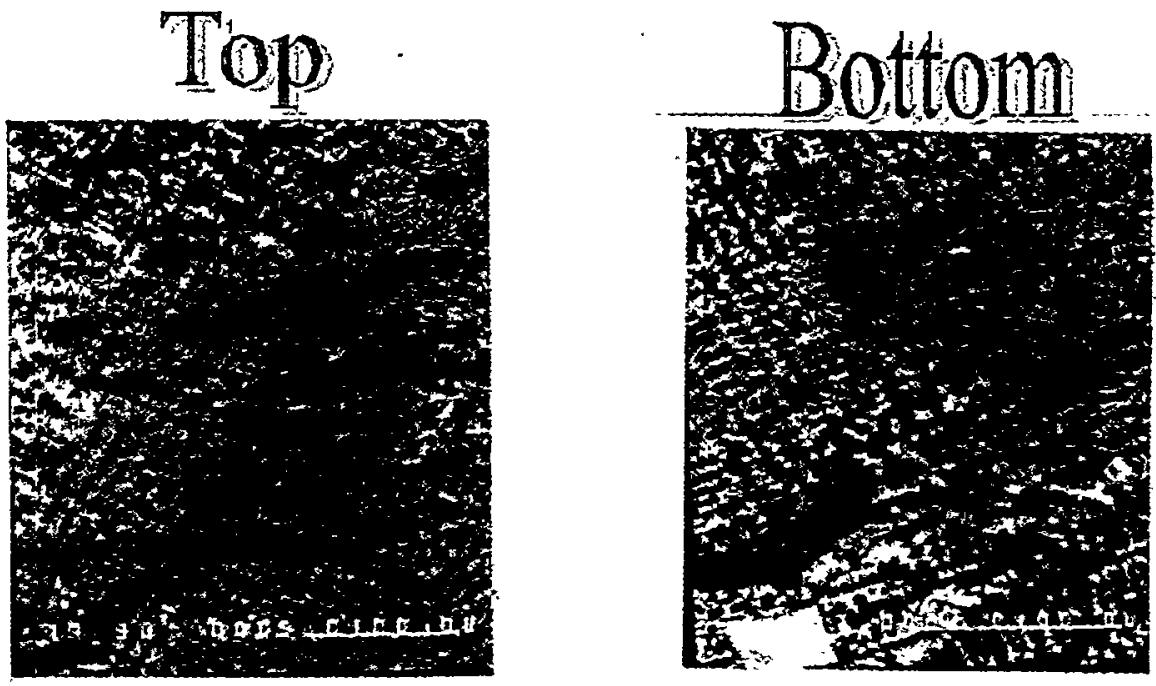

FIGURE 12: BEI OF BASE SLAG WITH 13.1WT\% CEO2 
Table XII: EMP Analysis of Base Slag with $13.1 \mathrm{wt} \% \mathrm{CeO}_{2}$

\begin{tabular}{|l|c|c|c|c|c|c|c|c|c|c|c|c|}
\hline & \multicolumn{9}{|c|}{ Weight\% } & \multicolumn{4}{c|}{ Atomic\% } \\
\hline Phase & Ca & Al & Ce & O & F & Total & Ca & Al & Ce & O & F & Total \\
\hline Top Light & 30.15 & 16.38 & 16.46 & 28.59 & 9.7 & 101.28 & 19.932 & 16.086 & 3.112 & 47.35 & 13.52 & 100 \\
\hline Top Dark & 47.92 & 0 & 3.68 & 0.377 & 47.81 & 99.79 & 31.785 & 0 & 0.698 & 0.626 & 66.89 & 100 \\
\hline Top Very Light & 9.03 & 16.11 & 50.55 & 25.44 & 2.237 & 103.36 & 7.791 & 20.653 & 12.48 & 55 & 4.073 & 100 \\
\hline Bottom Light & 29.59 & 18.93 & 17.36 & 29.45 & 5.57 & 100.89 & 19.971 & 18.972 & 3.351 & 49.78 & 7.925 & 100 \\
\hline Bottom Dark & 48.72 & 0 & 3.62 & 0.126 & 48.97 & 101.44 & 31.765 & 0 & 0.675 & 0.206 & 67.35 & 100 \\
\hline Bottom Very Light & 30.29 & 16.6 & 19.42 & 32.55 & 0.895 & 99.75 & 21.047 & 17.13 & 3.859 & 56.65 & 1.311 & 100 \\
\hline
\end{tabular}

\begin{tabular}{|l|c|c|c|c|c|c|}
\hline Overall Composition & 37.68135 & 9.053 & 11.41 & 15.92 & 26.59 & 100.65 \\
\hline Theoretical & 39.12 & 9.19 & 13.1 & 13.14 & 29.37 & \\
\hline
\end{tabular}
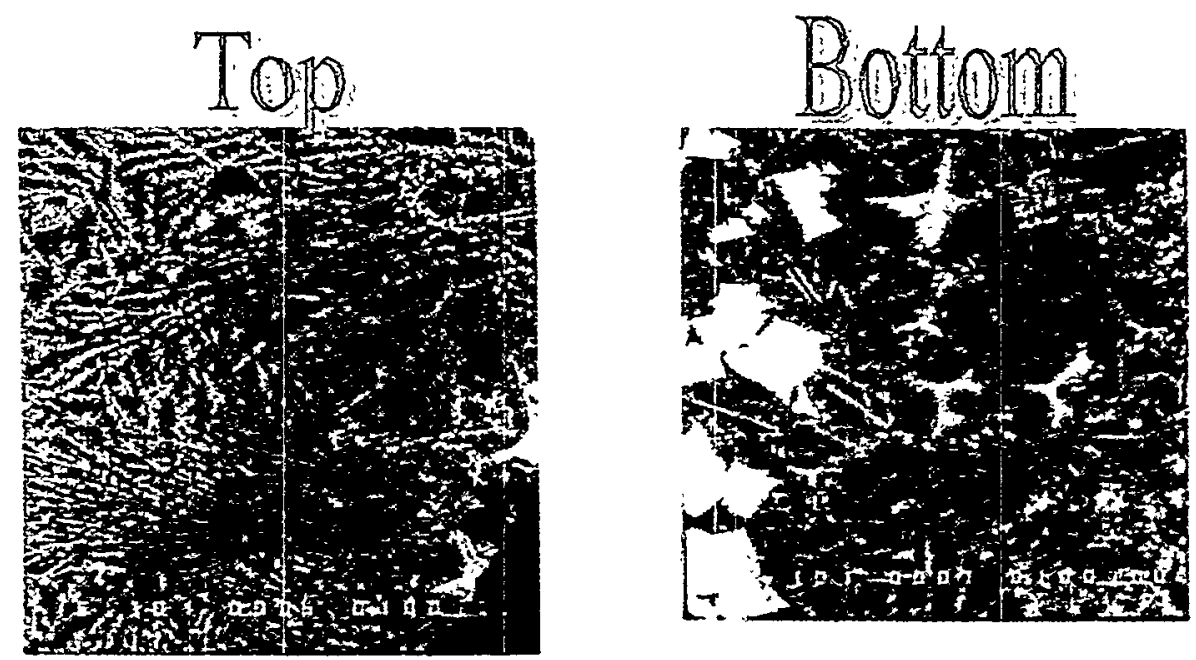

FIGURE 13: BEI OF BASE SLAG WITH 23WT\% CEO2

Table XIII: EMP Analysis of Base Slag with 23wt\% $\mathrm{CeO}_{2}$

\begin{tabular}{|c|c|c|c|c|c|c|c|c|c|c|c|c|}
\hline & \multicolumn{6}{|c|}{ Weight\% } & \multicolumn{6}{|c|}{ Atomic\% } \\
\hline Phase & $\mathbf{C a}$ & Al & $\mathrm{Ce}$ & 0 & $\mathbf{F}$ & Total & $\mathrm{Ca}$ & Al & $\mathrm{Ce}$ & 0 & $\mathbf{F}$ & Total \\
\hline Top Dark & 42.5 & 14.63 & 3.02 & 37.05 & 1.587 & 98.78 & 26.358 & 13.475 & 0.535 & 57.56 & 2.076 & 100 \\
\hline Top Very Light & 11.14 & 16.86 & 47.37 & 26.17 & 2.169 & 103.71 & 9.296 & 20.898 & 11.3 & 54.68 & 3.818 & 100 \\
\hline Top Crust Very Ligh & 8.78 & 16.09 & 50.22 & 25.64 & 2.186 & 102.91 & 7.573 & 20.624 & 12.4 & 55.43 & 3.980 & 100 \\
\hline Bottom Dark & 37.07 & 20.53 & 3.25 & 32.64 & 4.70 & 98.18 & 23.146 & 19.038 & 0.581 & 51.05 & 6.185 & 100 \\
\hline Bottom Very Light & 23.97 & 11.74 & 38.46 & 24.54 & 4.65 & 103.35 & 19.379 & 14.096 & 8.896 & 49.7 & 7.928 & 100 \\
\hline Bottom Very Light & 2.9608 & 14.21 & 62.2 & 21.89 & 2.997 & 104.26 & 2.8738 & 20.493 & 17.270 & 53.23 & 6.136 & 100 \\
\hline
\end{tabular}

\begin{tabular}{|l|c|c|c|c|c|c|}
\hline Overall Composition & 37.0904 & 15.01 & 10.67 & 35.17 & 1.687 & 99.636 \\
\hline Theoretical & 34.73 & 8.15 & 23 & 11.6 & 22.5 & \\
\hline
\end{tabular}




\subsection{Slag-Metal Partition Coefficient}

The foregoing observations have profound implication on the slag-metal partition coefficient. Since the $\mathrm{CeO}_{2}$ is completely soluble in the ESR slag $\left(60 \mathrm{wt} \% \mathrm{CaF}_{2}\right.$ $20 \mathrm{wt} \% \mathrm{CaO}-20 \mathrm{wt} \% \mathrm{Al}_{2} \mathrm{O}_{3}$ ), it implies that the $\mathrm{CeO}_{2}$ activity in the ESR slag will be extremely small since its concentration is not expected to exceed $2000 \mathrm{ppm}$. Therefore, from the $\mathrm{Ce} / \mathrm{CeO}_{2}$ equilibrium (Table 1), it is reasonable to expect that the $\mathrm{Ce}$ concentration in the metal phase will be below the detection limit $(<1 \mathrm{ppm})$. This has been observed experimentally.

The solidification behavior (crystallization path) of the slag system, as discussed in the previous section, suggests that it is possible for the slag skin over the ingot to have a higher ceria concentration than the slag cap; this is undesirable. This will be verified in future experiments. If high ceria partitioning between the slag skin and the cap is found to occur then the slag properties need to be tailored by changing its composition in order to avoid such partitioning.

\subsection{Volatilization Study}

The purpose of the study is to determine the rate at which the base slag and the base slag mixed with different amounts of ceria volatilizes as a function of temperature and the chemical nature of the volatile species. This is accomplished using a thermogravimetric (TG) balance and a quadropole mass analyzer. Also, the volatile species were condensed and chemically analyzed.

The TG balance used was a CAHN D-100 Series system that is run with CAHN D-100 Series software version 2.0. The experiments are conducted in a graphite crucible suspended in a purified argon atmosphere to prevent oxidation of the crucible material. The arrangement is schematically shown in Figure 14. In order to measure the volatilization rate of the slag with $\mathrm{CeO}_{2}$, it was necessary to reduce the $\mathrm{CeO}_{2}$ to $\mathrm{Ce}_{2} \mathrm{O}_{3}$

prior to melting the slag, so that the-vaporization rate could be attributed to slag volatilization instead of to $\mathrm{CeO}_{2}$ reduction. Under the experimental conditions maintained in the TG experiments, $\mathrm{Ce}_{2} \mathrm{O}_{3}$ was the stable phase (Figure 15). Typical TG results with 
base slag and base slag with ceria are shown in Figures 16 and 17. The important runs to date and the calculated evaporation rates are listed in Table XIV. The natural logarithm of the evaporation rate as a function of inverse temperature for the runs reported in Table XIV are shown in Figure 18. From Figure 18, it can be seen that the volatilization rate of the base slag and the base slag with ceria did not differ much and followed an Arrhenius behavior. The volatilization rate of the base slag as a function of temperature can be expressed as:

$$
R=3445.26 \exp \left(-\frac{37955.09}{T}\right)
$$

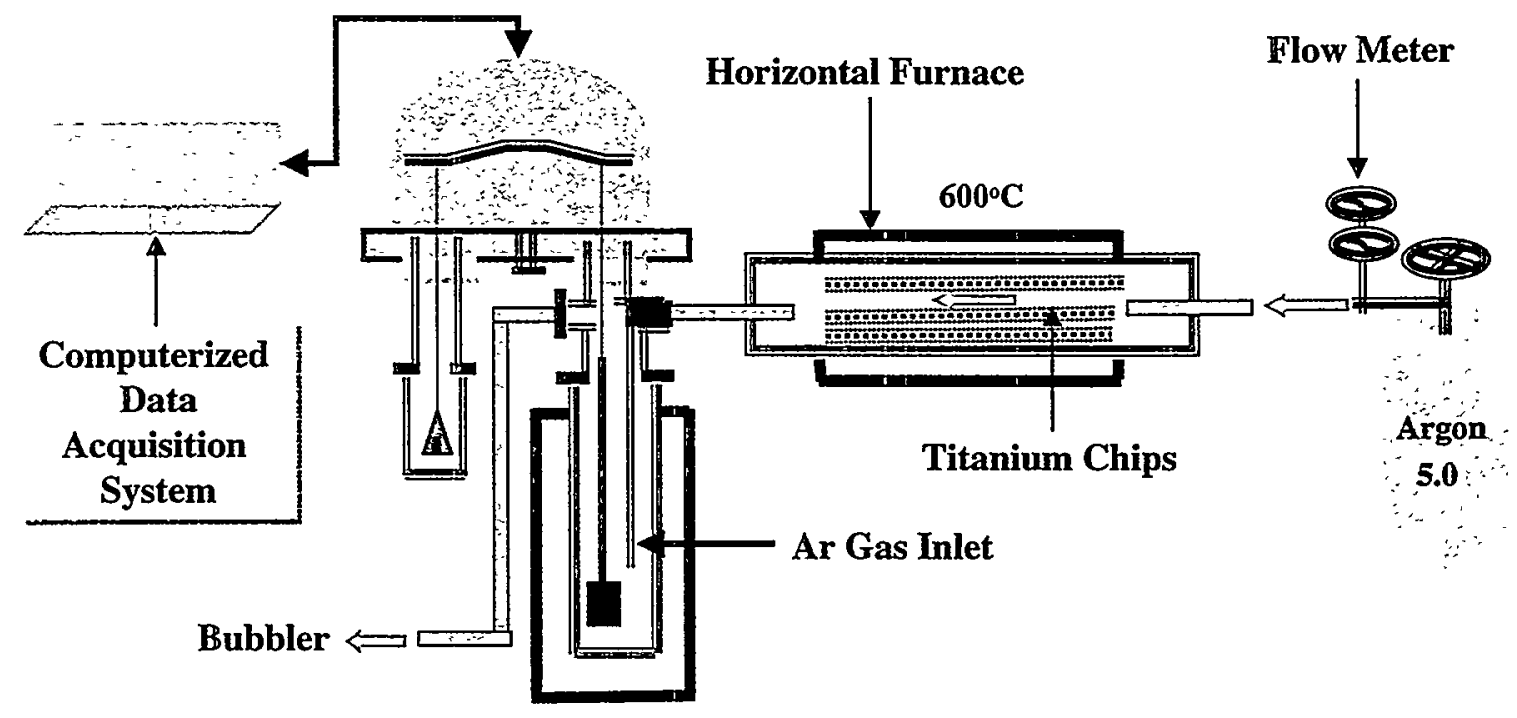

FIGURE 14: THERMOGRAVIMETRY EXPERIMENTAL SET UP TO STUDY VOLATILIZATION 


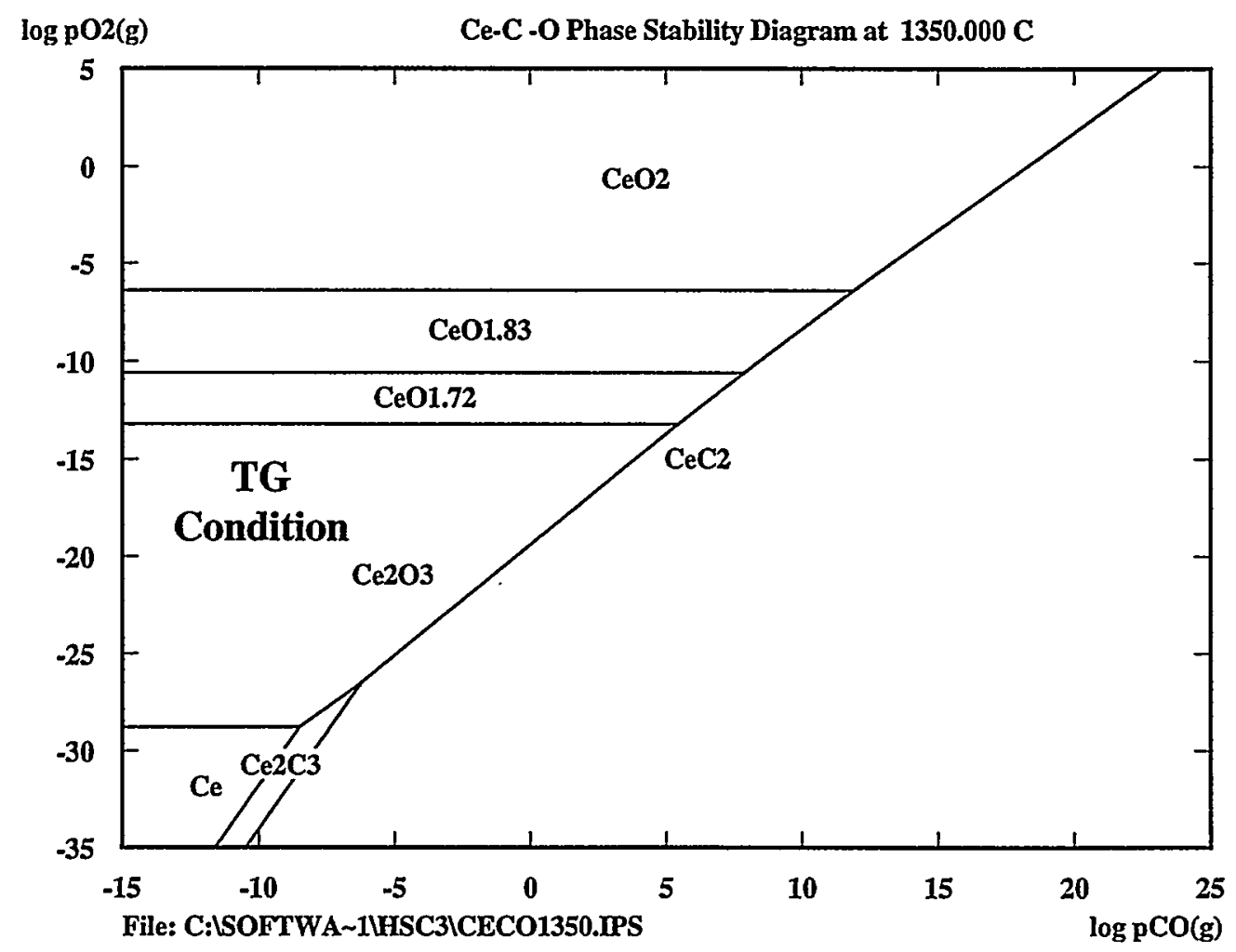

FIGURE 15: PHASE DIAGRAM OF CE-C-O SYSTEM

Experiment Conducted on 2-24-99 (Pure Base Slag)

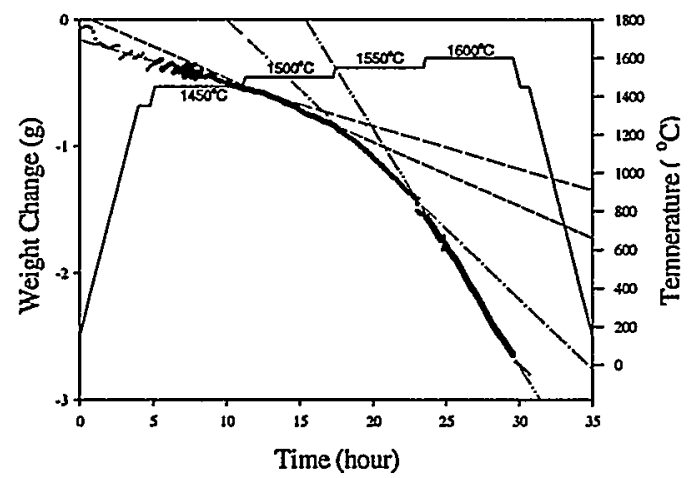

Experiment Conducted on 2-19-99 (100 ppm $\mathrm{CeO}_{2}$ in Base Slag)

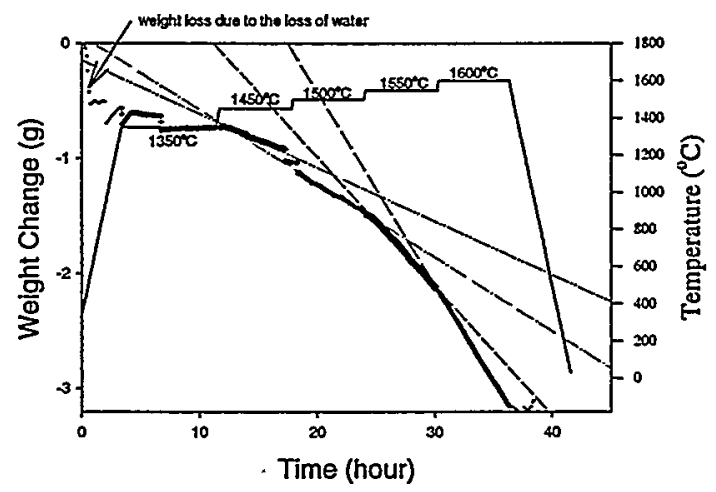

FIGURE 16: THERMOGRAVIMETRIC

EXPERIMENT WITH BASE SLAG

FIGURE 17: THERMOGRAVIMETRIC

EXPERIMENT OF BASE SLAG WITH

100PPM CEO 
Table XIV: Thermogravimetric Experiments and Results

\begin{tabular}{|c|c|c|c|c|}
\hline Experiment Type & $\begin{array}{c}\text { Base Slag Mass } \\
\text { (g) }\end{array}$ & $\begin{array}{c}\mathrm{CeO}_{2} \text { Mass } \\
\text { (g) }\end{array}$ & $\begin{array}{c}\text { Temperature } \\
\left({ }^{\circ} \mathrm{C}\right)\end{array}$ & $\begin{array}{c}\text { Volatilization } \\
\text { Rate } \\
\text { (g/cm2-sec.) }\end{array}$ \\
\hline Pure Base Slag & 37.687 & & 1450 & $1.010 \mathrm{E}-06$ \\
\hline Pure Base Slag & 37.687 & & 1500 & $1.500 \mathrm{E}-06$ \\
\hline Pure Base Slag & 37.687 & & 1550 & $3.280 \mathrm{E}-06$ \\
\hline Pure Base Slag & 37.687 & & 1600 & $5.560 \mathrm{E}-06$ \\
\hline 100ppm Ceria & 38.017 & 0.00382 & 1450 & $1.378 \mathrm{E}-06$ \\
\hline 100ppm Ceria & 38.017 & 0.00382 & 1500 & $1.892 \mathrm{E}-06$ \\
\hline 100ppm Ceria & 38.017 & 0.00382 & 1550 & $3.313 \mathrm{E}-06$ \\
\hline 100ppm Ceria & 38.017 & 0.00382 & 1600 & $4.958 \mathrm{E}-06$ \\
\hline 40000ppm Ceria & 36.009 & 1.440 & 1450 & $7.006 \mathrm{E}-07$ \\
\hline 40000ppm Ceria & 36.009 & 1.440 & 1500 & $2.193 \mathrm{E}-06$ \\
\hline 40000ppm Ceria & 36.009 & 1.440 & 1550 & $4.001 \mathrm{E}-06$ \\
\hline $40000 \mathrm{ppm}$ Ceria & 36.009 & 1.440 & 1600 & $6.286 \mathrm{E}-06$ \\
\hline 100000ppm Ceria & 34.896 & 3.4896 & 1450 & $8.921 \mathrm{E}-07$ \\
\hline $100000 \mathrm{ppm}$ Ceria & 34.896 & 3.4896 & 1500 & $2.318 \mathrm{E}-06$ \\
\hline $100000 \mathrm{ppm}$ Ceria & 34.896 & 3.4896 & 1550 & $4.002 \mathrm{E}-06$ \\
\hline $100000 \mathrm{ppm}$ Ceria & 34.896 & 3.4896 & 1590 & $5.965 \mathrm{E}-06$ \\
\hline
\end{tabular}

Temperature (K)

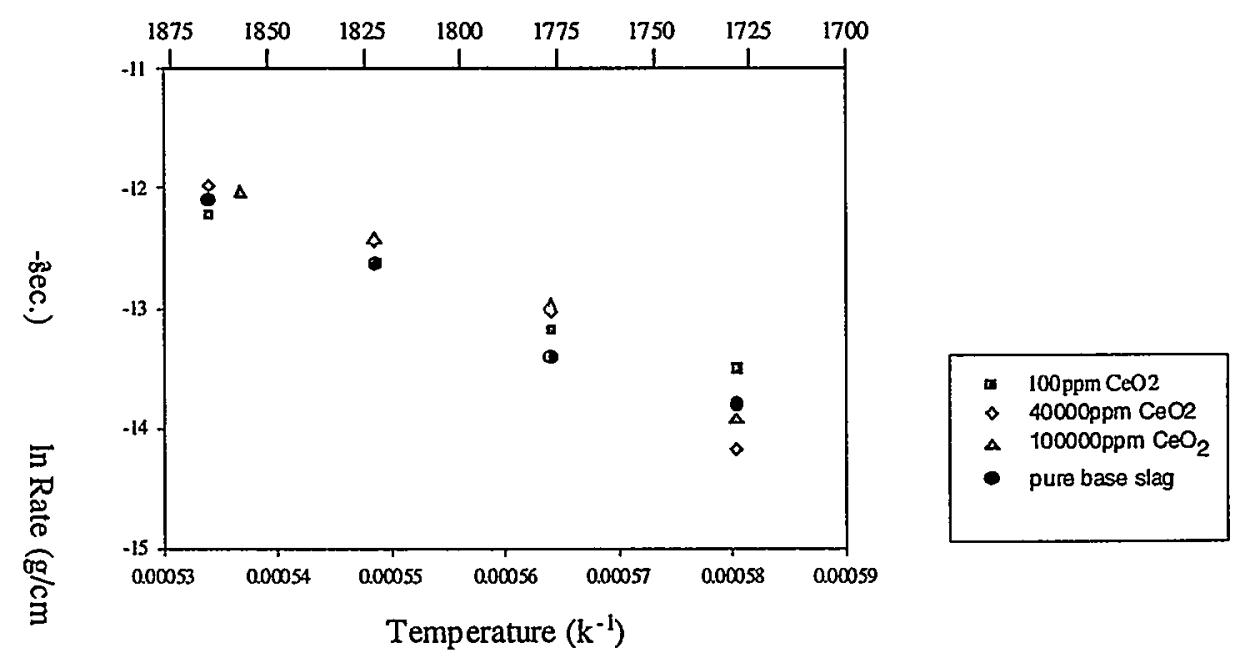

FIGURE 18: COMPARISON OF RESULT OF VOLATILIZATION EXPERIMENTS 


\subsection{Volatile Species}

The experimental setup used to condense the volatile slag species onto a water-cooled copper coil is shown in Figure 19. The condensed vapor was an amorphous powder. Therefore, in order to analyze by $\mathrm{X}$-ray diffraction, an attempt was made to crystallize the powder by annealing at $1000^{\circ} \mathrm{C}$. The diffraction pattern showed the presence of $\mathrm{CaF}_{2}$ (Figure 20). In order to determine the uncondensed volatile species, the volatile gas from the base slag was passed through a quadropole mass analyzer as shown in Figure 21. The spectra from the mass analyzer (Figure 22) showed presence of $\mathrm{AlF}_{3}$ among the volatile species.

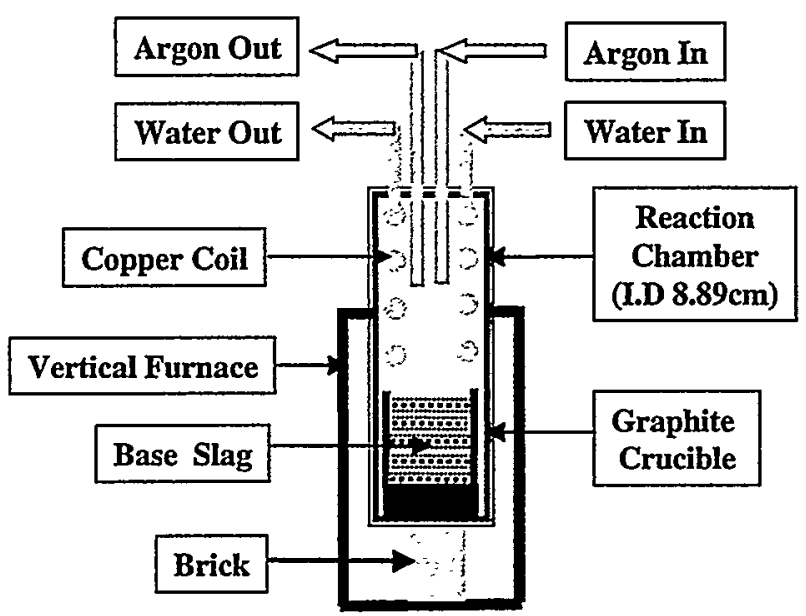

$$
\begin{aligned}
\Rightarrow \text { Base slag } 250 \text { gram } \\
\Rightarrow \text { Graphite crucible } \\
\rightarrow \text { Inner diameter } 6.985 \mathrm{~cm} \\
\quad \rightarrow \text { Depth } 128 \mathrm{~cm} \\
\Rightarrow \text { Argon flow rate } 2.696 \mathrm{l} / \mathrm{min} \text {. } \\
\Rightarrow \text { Held at } 1500^{\circ} \mathrm{C} \text { for } 6 \text { hours } \\
\Rightarrow \text { Vapors condensed on water } \\
\text { cooled copper coil and } \\
\text { recrystallized } \\
\Rightarrow \text { for X-ray diffraction analysis }
\end{aligned}
$$

FIGURE 19: EXPERIMENTAL SETUP FOR IDENTIFICATION OF VOLATILE SPECIES

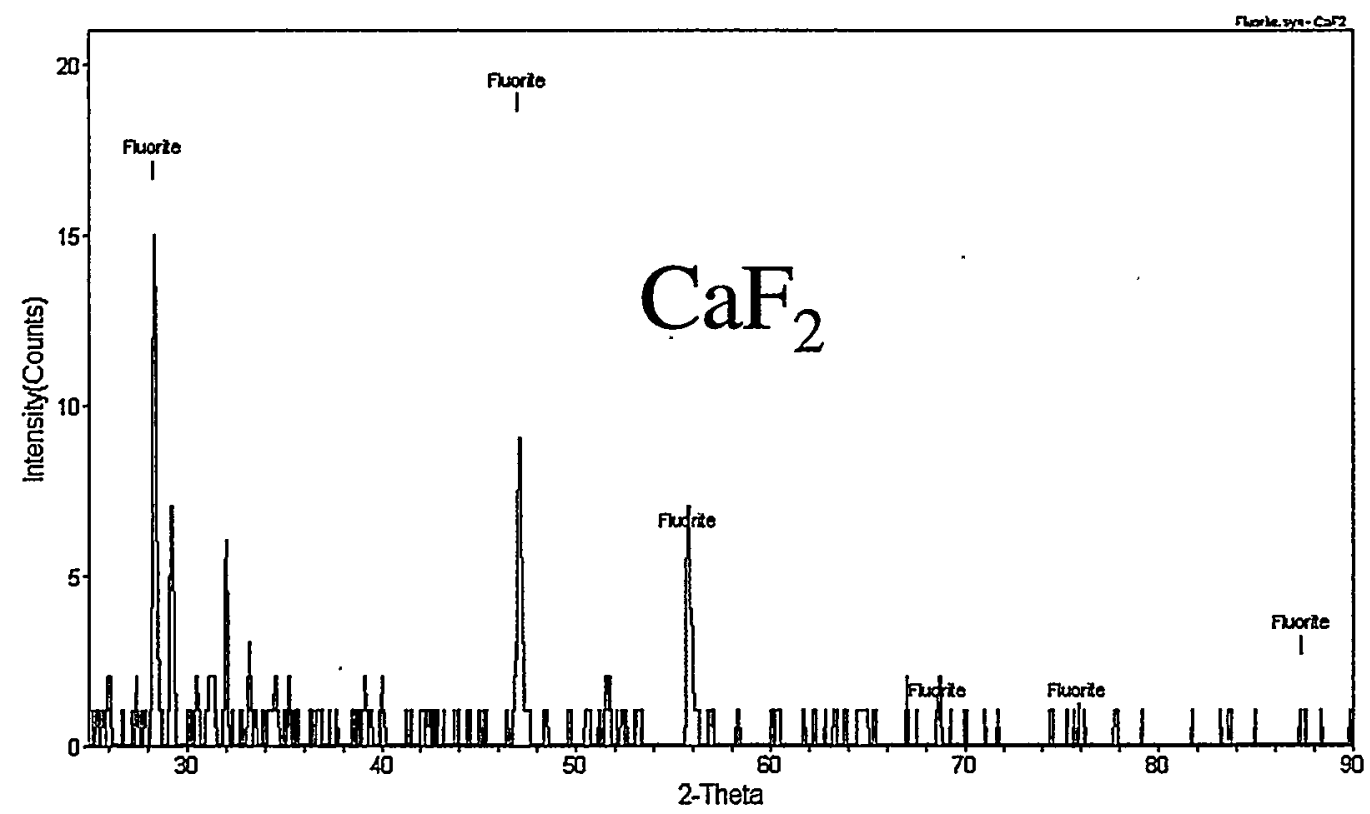

FIGURE 20: X-RAY DIFFRACTION RESULT 


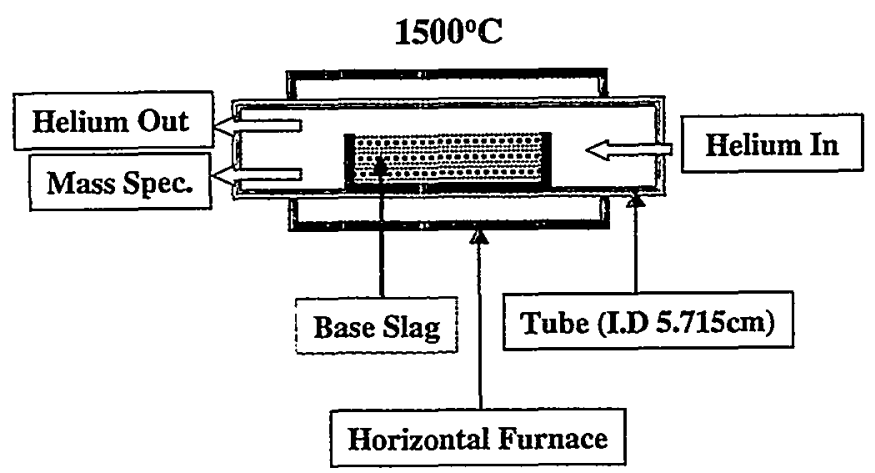

$\Rightarrow$ Base slag $141.5 \mathrm{~g}$

$\Rightarrow$ Graphite Tray

$\rightarrow$ Length $13.335 \mathrm{~cm}$

$\rightarrow$ Width $3.81 \mathrm{~cm}$

$\rightarrow$ Depth $25.4 \mathrm{~cm}$

$\Rightarrow$ Helium flow rate $0.2 \mathrm{l} / \mathrm{min}$.

$\Rightarrow$ Held at $1500 \mathrm{C}$ for $6 \mathrm{hr}$

$\Rightarrow$ Mass Spectrometer used for vapor specie analysis

FIGURE 21: EXPERIMENTAL SETUP FOR IDENTIFICATION OF VOLATILE SPECIES

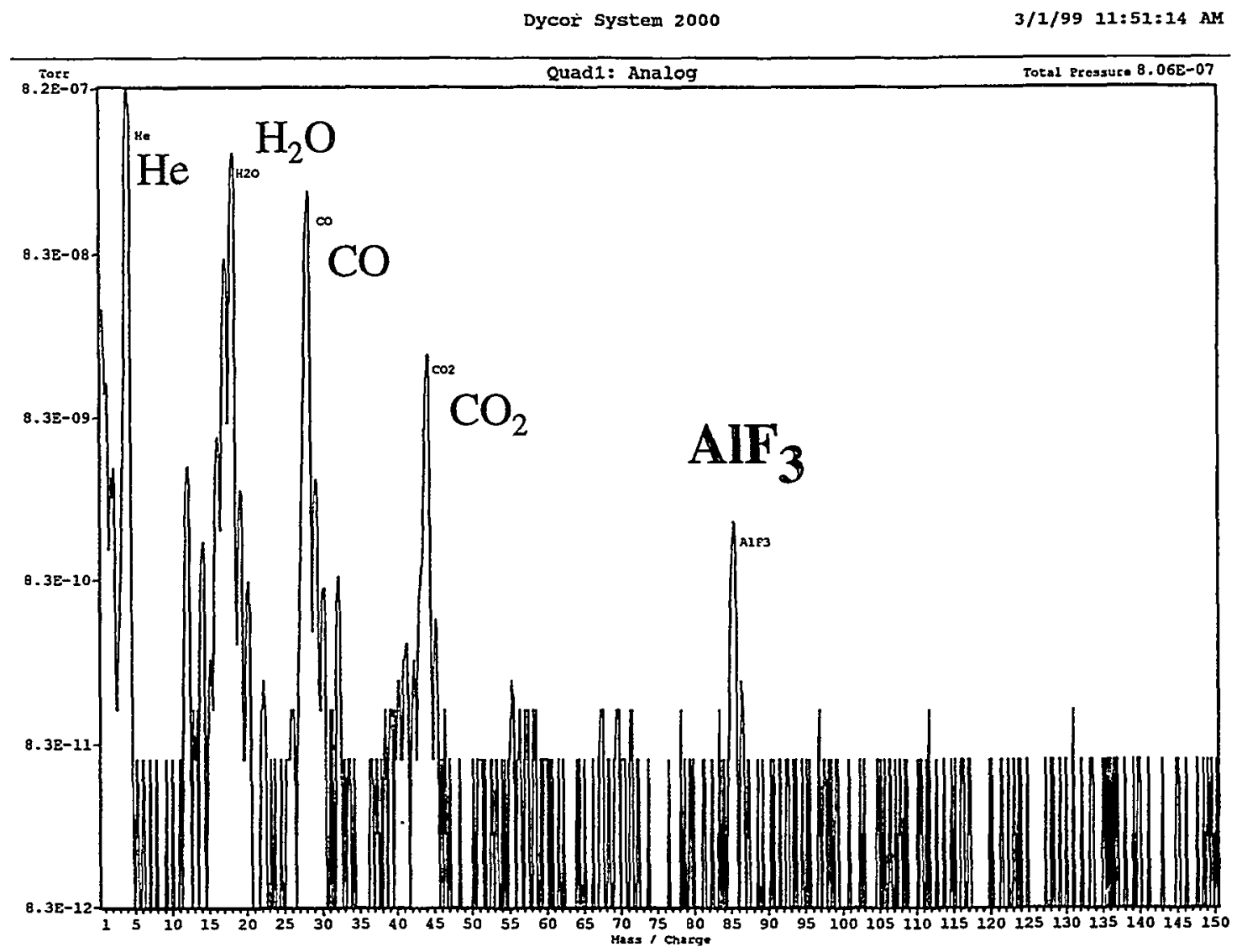

FIGURE 22: MASS SPECTROSCOPY ANALYSIS OF THE VOLATILE SPECIES 


\subsection{Viscosity Studies}

The viscosity of the base slag was measured using an inner cylinder rotation technique. The schematic of the set up is shown in Figure 23. The viscosity measurements were conducted as a function of temperature. The results are shown in Table XV and plotted in Figure 24. From Figure 24, it is apparent that there is a drastic increase in the viscosity of the base slag as the temperature decreases from $1400^{\circ} \mathrm{C}$ to $1390^{\circ} \mathrm{C}$. This means that the base slag does not remain as a single phase below $1390^{\circ} \mathrm{C}$. This conclusion is consistent with the liquidus temperature of the base slag as suggested in Figure 2. Furthermore, above $1400^{\circ} \mathrm{C}$ the viscosity is not a strong function of the temperature indicating that the slag is fluid and does not have long polymeric chains. The measured volatilization rate is not significant to change the fluorine content of the slag during the ESR process and therefore the slag viscosity is not expected to change.

Table XV: Base Slag Viscocity Data as a Function of Temperature

\begin{tabular}{|c|c|}
\hline $\begin{array}{c}\text { Temperature } \\
\text { (k) }\end{array}$ & $\begin{array}{c}\text { Viscocity } \\
\text { (dPa.s) }\end{array}$ \\
\hline 1500 & 0.868 \\
\hline 1500 & 0.707 \\
\hline 1450 & 0.748 \\
\hline 1400 & 0.708 \\
\hline 1390 & 7.461 \\
\hline 1380 & 6.806 \\
\hline 1370 & 19.301 \\
\hline
\end{tabular}

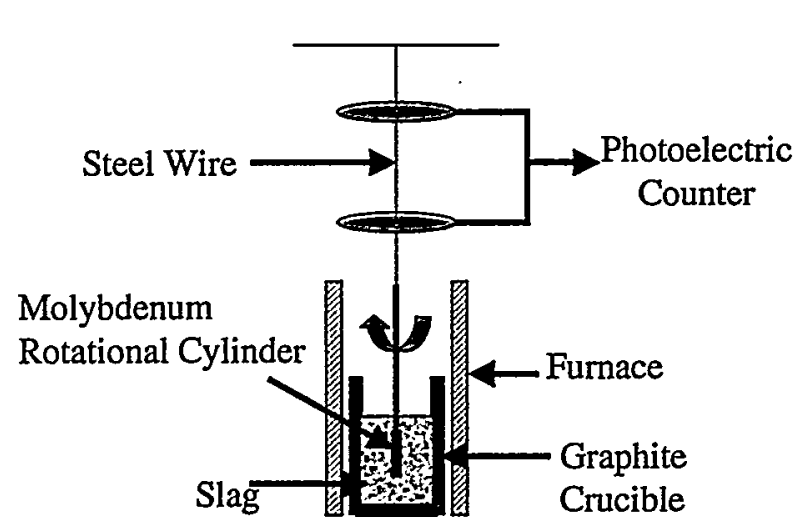

FIGURE 23: SET UP FOR VISCOSITY MEASUREMENT

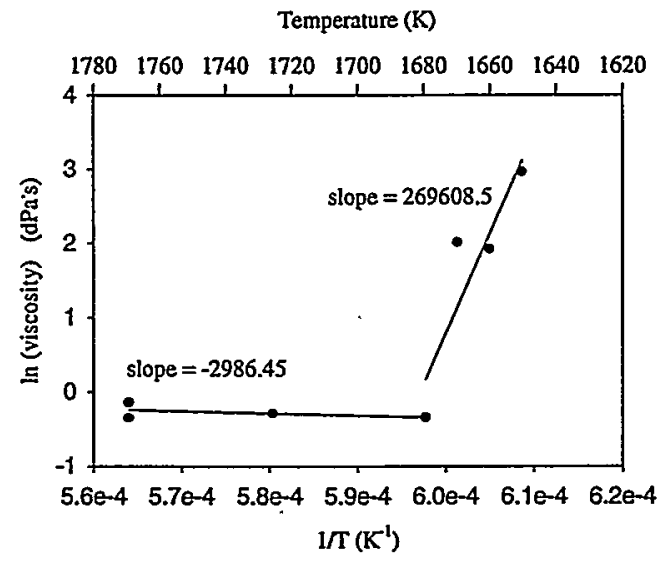

FIGURE 24: ARRHENIUS PLOT OF BASE SLAG VISCOSITY 


\subsection{Surface Tension Measurements}

The surface tension measurements were made using the maximum bubble pressure method. The schematic of the set up is shown in Figure 25. The measurements were made as a function of temperature. The results are shown in Table XVI and plotted in Figure 26. Figure 26 shows that the surface tension of the molten slag follows an Arrhenius behavior.

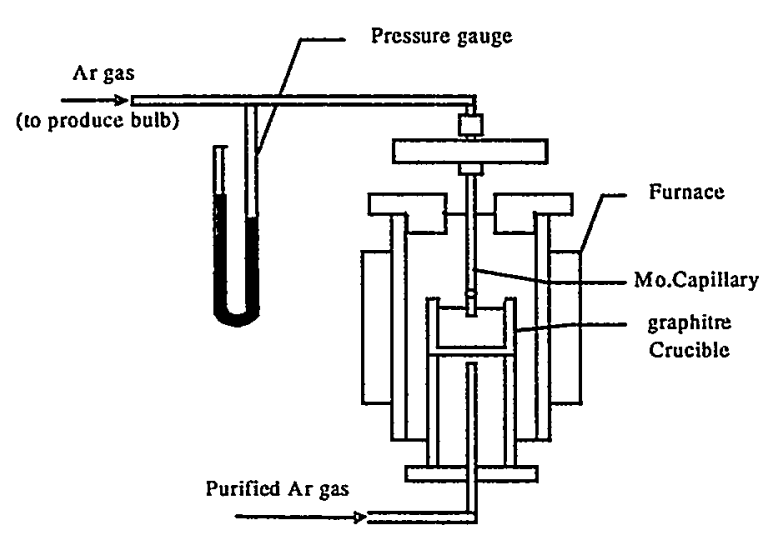

FIGURE 25: SET UP FOR SURFACE TENSION

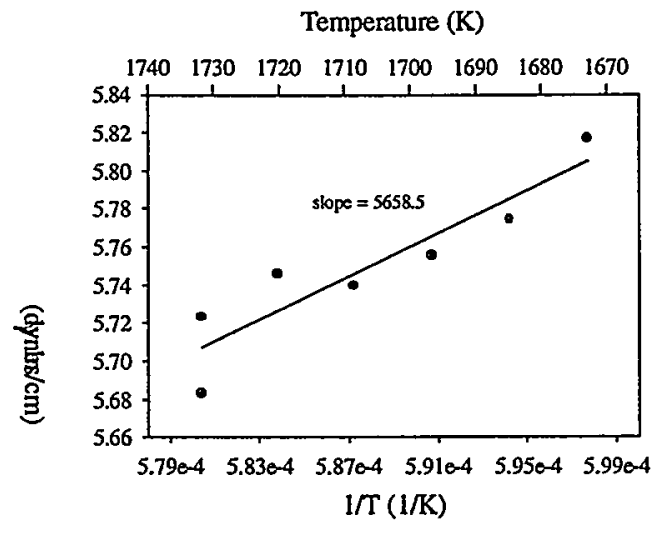

FIGURE 26: ARRHENIUS PLOT OF BASE SLAG SURFACE TENSION

Table XVI: Surface Tension Data of Base Slag as a Function of Temperature

\begin{tabular}{|c|c|}
\hline $\begin{array}{c}\text { Temperature } \\
(\mathbf{k})\end{array}$ & $\begin{array}{c}\text { Surface Tension } \\
(\mathbf{d y n e} / \mathbf{c m})\end{array}$ \\
\hline 1673 & 336 \\
\hline 1683 & 322 \\
\hline 1693 & 316 \\
\hline 1703 & 311 \\
\hline 1713 & 313 \\
\hline 1723 & 306 \\
\hline 1723 & 294 \\
\hline
\end{tabular}

\subsection{Electrical Conductivity Study}

The electrical conductivity was measured using an $\mathrm{AC}$ impedance method with 2 point electrodes, as shown in Figure 27. The cell constant was determined by measuring the electrical conductivity of a $\mathrm{KCl}$ standard solution at $25^{\circ} \mathrm{C}$. The electrical conductivity of 
the base slag was measured as a function of temperature (Table XVII). The single Arrhenius behavior (Figure 28) above and below the single-phase region (around $1390^{\circ} \mathrm{C}$ ) indicates that the conduction mechanism remains primarily unchanged, probably dominated by the $\mathrm{F}$ ions.

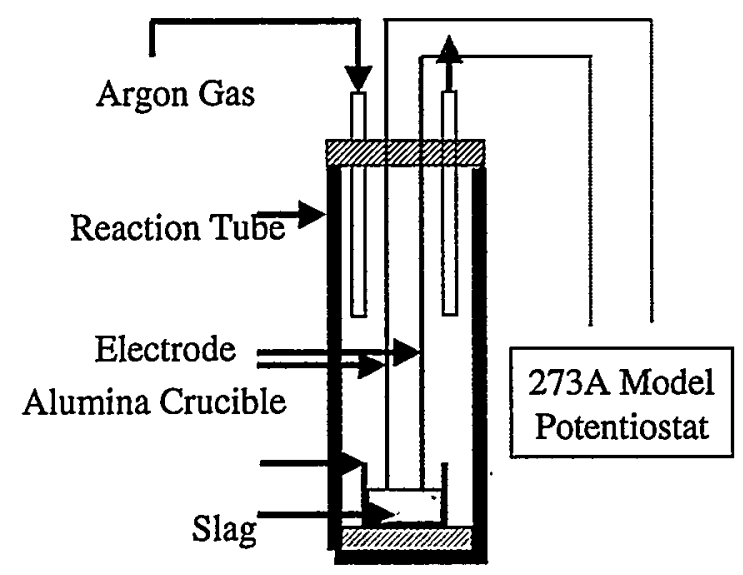

FIGURE 27: SET UP OF ELECTRICAL CONDUCTIVITY

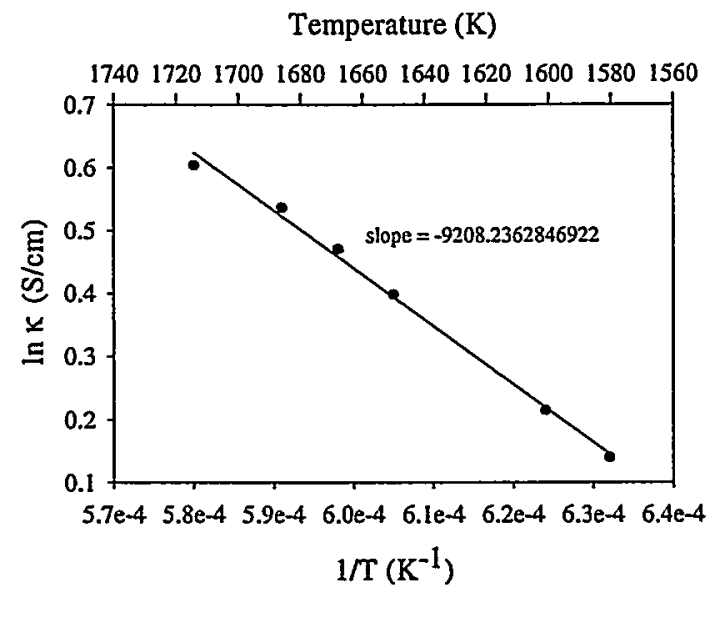

FIGURE 28: ARRHENIUS PLOT OF CONDUCTIVITY

Table XVII: Conductivity Data of Base Slag as a Function of Temperature

\begin{tabular}{|c|c|}
\hline Temperature & Conductivity \\
\hline 1583 & 1.15 \\
\hline 1603 & 1.24 \\
\hline 1653 & 1.49 \\
\hline 1673 & 1.60 \\
\hline 1693 & 1.71 \\
\hline 1723 & 1.83 \\
\hline
\end{tabular}

A novel calibration free conductivity cell has been developed that measures the molten slag impedance as a function of electrode height. The electrodes are coaxial and symmetrical as shown in Figure 29. From the slope of the linear plot of slag impedance as a function of the depth of electrode immersed, the slag conductivity is calculated. The technique has been successfully developed and it will be used to measure the slag conductivity in the future. 


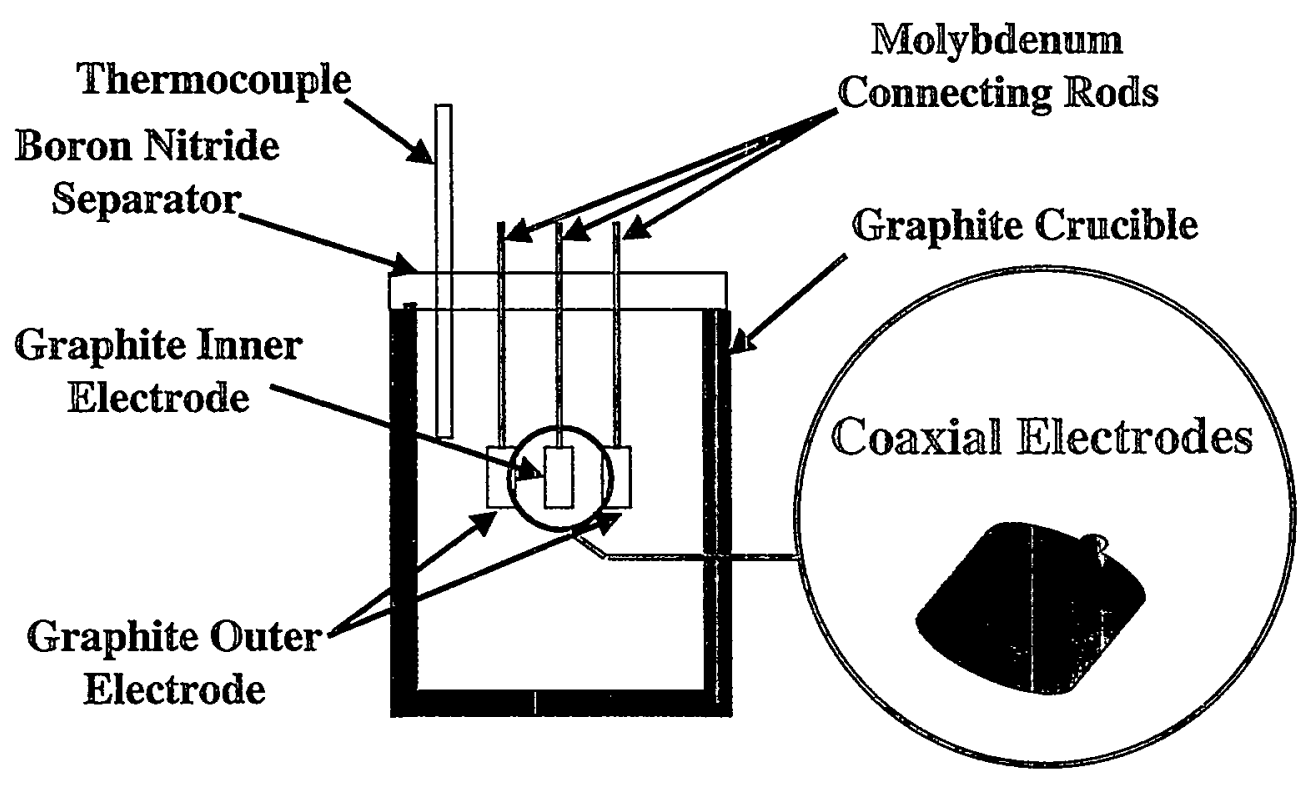

FIGURE 29: CALIBRATION FREE CONDUCTIVITY CELL 


\subsection{Concluding Remarks}

The ESR base slag $\left(60 \mathrm{wt} \% \mathrm{CaF}_{2}-20 \mathrm{wt} \% \mathrm{CaO}-20 \mathrm{wt} \% \mathrm{Al}_{2} \mathrm{O}_{3}\right)$ has a high capacity for incorporating $\mathrm{CeO}_{2}$ (surrogate for $\mathrm{Pu}$ and $\mathrm{U}$ oxides) and results in excellent slag-metal separation of the contaminant. However, it is also desirable to minimize the slag skin around the ingot, concentrate the radioactive contaminants in the slag cap over the ingot, and improve the surface quality of the ingot. In order to address these issues, the interfacial tension, viscosity, and solidification behavior were determined. Future experiments will attempt to alter these properties by adding varying amounts of $\mathrm{TiO}_{2}$ and deoxidants and study the effect on the slag skin over the ingot and the slag cap. The measured slag volatilization followed Arrhenius behavior. Volatilization rates of the base slag were low, and ceria impurity incorporated in the slag does not significantly alter the volatilization rate. The volatile species were primarily $\mathrm{CaF}_{2}$ and $\mathrm{AlF}_{3}$. The electrical conductivity of the slag follows an Arrhenius behavior and provides efficient Joule Heating during the ESR process. Our ESR melt decontamination studies are continuing, and further results will be reported later. 


\section{References}

1. T.E. Bechtold, "Winco Metal Recycle Annual Report FY 1993," WINCO-1172, Prepared for the U.S. Department of Energy, Idaho Field Office, 1993.

2. J.M.R. Buckentin, "PhD Thesis in Materials Science-Melt Decontamination of Radioactive Stainless Steel by Electro-Slag Remelting," Oregon Graduate Institute of Science and Technology, March 1996.

3. E.M. Levin, C.R. Robbins and H.F. McMurdie, "Phase Diagrams for Ceramists Vol.1," Edited by M.K. Reser, Published by the American Ceramic Society, Columbus, Ohio, 1964.

4. S.A. Worcester, L.G. Twidell, D. Webber, D.J. Paolini, T.A. and Weldon, "Report on Decontamination and Decarburization of Stainless Steel and Carbon Steel by Melt Refining," Prepared for Lockheed Idaho Technologies Company Under Subcontract No. C85-110767 and the U.S. Department of Energy. 
(2) MS 0715 Sylvia Chapman, 6130

MS 1134 Dave Melgaard, 1846

MS 1134 Jim Van Den Avyle, 1846

MS 0706 Marty Molecke, 6113

MS 9018 Central Technical Files, 8940-2

(2) MS 0899 Technical Library, 4916

MS 0612 Review and Approval Desk, 4912

for DOE/OSTI 